\title{
Finding THE PoINT OF NOVELTy IN SOFTWARE PATENTS
}

\author{
Bernard Chao'
}

\begin{abstract}
The issue of patentable subject matter eligibility is in considerable flux. In 2012, the Supreme Court set forth a confusing new framework for determining patent eligibility. The decision in Mayo v. Prometheus cast serious doubt on the continued viability of many software patents. Indeed, a split quickly emerged in the Federal Circuit. As a result, it was unclear whether adding computer limitations to an otherwise unpatentable concept somehow renders the concept patent-eligible. In an attempt to settle this question, the Federal Circuit granted a petition to rehear the issue en banc. But in CLS Bank Int'l v. Alice Corp., the judges could not find common ground and the decision contained seven separate opinions reflecting at least three distinct approaches. Thus, there remains a pressing need to find a common analytical framework for deciding software patent eligibility questions.

There is a way out of the current morass without departing from precedent. In Mayo, the Supreme Court implicitly revived long rejected point-of-novelty thinking. In an earlier essay, I expanded on that approach and offered a general framework for making patentable subject matter eligibility determinations. This Article applies this approach to software patents. Specifically, it explains that the key to determining whether a software patent covers eligible subject matter is assessing the strength of the connection between the patent's point of novelty and physical devices found in the other claim limitations. This test serves to rein in harmful business method software patents without affecting more deserving industrial patents. Thus, the test is justified from both doctrinal and policy perspectives.
\end{abstract}

(C) 2013 Bernard Chao.

† Assistant Professor, University of Denver Sturm College of Law. I would like to thank Brian Love, Kevin Emerson Collins, Viva Moffat, Dmitry Karshtedt, Harry Surden, Justin Pidot, John Soma, and Ian Farrell for their comments on earlier drafts of this Article. 


\section{TABLE OF CONTENTS}

I. INTRODUCTION. 1218

II. CATEGORIES OF SOFTWARE PATENTS.

III. THE FRACTURED JURISPRUDENCE

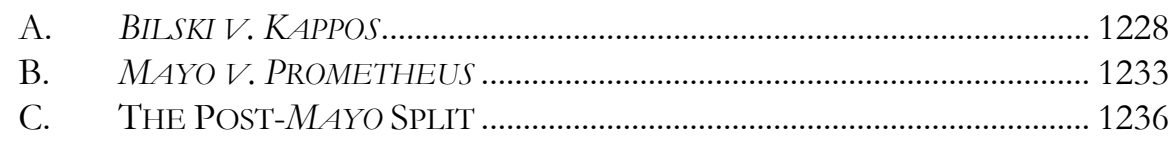

IV. A POINT-OF-NOVELTY RESOLUTION …………............................... 1240

V. POSTSCRIPT: A DEEPENING SCHISM …………………….............. 1249

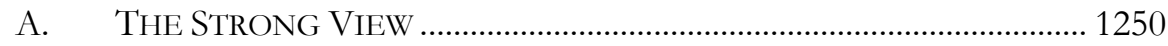

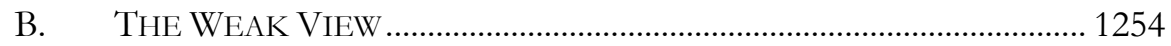

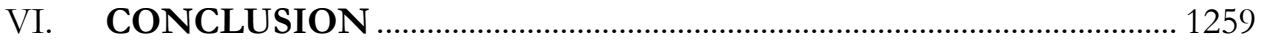

\section{INTRODUCTION}

Last year, in Mayo v. Prometheus, the Supreme Court made another attempt to define the scope of patentable subject matter. ${ }^{1}$ A unanimous Supreme Court held that the personalized medicine dosing process invented by Prometheus Laboratories was not eligible for patent protection because the process was effectively an unpatentable law of nature. ${ }^{2}$ Although the decision did not directly address software patents, it set forth a confusing framework for subject-matter patent eligibility that will apply to software patents.

In the wake of Mayo, the Federal Circuit has already issued two conflicting decisions on the eligibility of software patents. ${ }^{3}$ Although both cases involved patents on business concepts implemented through software, the two decisions applied different approaches to patentability and arrived at different outcomes. On July 9, 2012, in CLS Bank International v. Alice Corp., a

1. Mayo Collaborative Servs. v. Prometheus Labs., Inc., 132 S. Ct. 1289 (2012). Just two years earlier, the Supreme Court decided Bilski v. Kappos, 130 S. Ct. 3218 (2010), a decision that ostensibly set out the rules for determining subject matter eligibility under \101. See also Mayo, 132 S. Ct. at 1293 ("[L]aws of nature . . are not patentable.") (internal quotation marks omitted) (citing Bilski, $130 \mathrm{~S}$. Ct. at 3233-34). Section 101 provides that "[w]hoever invents or discovers any new and useful process, machine, manufacture, or composition of matter, or any new and useful improvement thereof, may obtain a patent therefor, subject to the conditions and requirements of this title." 35 U.S.C. $\int 101$ (2012).

2. Mayo, 132 S. Ct. at 1294.

3. CLS Bank Int'l v. Alice Corp. (CLS Bank I), 685 F.3d 1341 (Fed. Cir. 2012), reh'g en banc granted, opinion vacated, 484 F. App'x 559 (Fed. Cir. 2012), aff'd en banc, 717 F.3d 1269 (Fed. Cir. 2013); Bancorp Servs. v. Sun Life Assurance Co., 687 F.3d 1266 (Fed. Cir. 2012). 
panel of the Federal Circuit found that patents covering a trading system platform for exchanging obligations contained patent-eligible subject matter. ${ }^{4}$ Less than a month later, in Bancorp Services v. Sun Life Assurance Co., a different panel found that patents covering a system for administering and tracking life insurance values were invalid because they covered an unpatentable abstract idea. ${ }^{5}$ Unsurprisingly, the Federal Circuit decided to resolve this split and granted a petition for an en banc rehearing in CLS Bank. ${ }^{6}$ Specifically, the court asked the parties: "[W] hat test should the court adopt to determine whether a computer-implemented invention is a patent ineligible 'abstract idea' ... . ?"?

This Article originally set out to respond to this question. However, shortly before it went to press, the Federal Circuit issued its en banc decision in CLS Bank. ${ }^{8}$ Unfortunately, the seven separate opinions found in this split decision only added to the confusion. ${ }^{9}$ Part V of this Article is a "postscript" describing these different views. Although a majority of seven judges found that the method and computer-readable claims at issue were not patenteligible, the court split evenly (5-5) on the eligibility of the system claims. ${ }^{10}$ Moreover, no majority could agree on a common analytical approach. Instead, the 135-page decision reflected at least three distinct analytical approaches. ${ }^{11}$ The judges themselves characterized the decision as "irreconcilably fractured", and "devoid of consensus." 13 Thus, there continues to be a pressing need to find a "consistent, cohesive, and accessible" framework for determining when software patents cover patenteligible subject matter under $₫ 101$ of the Patent Act. ${ }^{14}$

4. CLS Bank I, 685 F.3d at 1356 (Linn, Prost \& O’Malley, JJ.).

5. Bancorp, 687 F.3d at 1281 (Lourie, Prost \& Wallach, JJ.).

6. CLS Bank Int'l v. Alice Corp. (CLS Bank II), 484 F. App'x 559 (order granting hearing en banc).

7. Id.

8. CLS Bank Int'l v. Alice Corp. (CLS Bank III), 717 F.3d 1269 (Fed. Cir. 2013) (en banc).

9. See id.

10. The result was that the district court's holding that none of the claims were drawn to eligible subject matter was affirmed. CLS Bank III, 717 F.3d at 1273 (per curiam).

11. See discussion infra Part V (discussing the opinions of Judge Lourie (concurring), Chief Judge Rader (concurring in part and dissenting in part), and Judge Newman (concurring in part and dissenting in part)).

12. CLS Bank III, 717 F.3d at 1314. (Moore, J., dissenting in part).

13. Id. at 1321 (Newman, J., concurring in part and dissenting in part).

14. Id. at 1277 (Lourie, J., concurring) (discussing the need for a workable approach in $\int 101$ jurisprudence). 
Building on earlier work, ${ }^{15}$ this Article attempts to provide that framework. The suggested approach does not attempt to make any fundamental changes to $\int 101$ in hopes of finding the "best" solution for patent law. Rather, the proposed approach seeks to provide a practical and coherent framework that sensibly brings the doctrine of subject-matter patentability as applied to software patents in line with the Mayo decision.

Laws of nature, natural phenomena, and abstract ideas are not patentable. ${ }^{16}$ But identifying when a patent covers one of these unpatentable concepts (as opposed to an application of such a concept-which is patentable ${ }^{17}$ ) has proven to be quite difficult. The Federal Circuit panel in Mayo dissected the claims of Prometheus' personalized medicine patent and held that they did not add "enough" to an unpatentable law of nature to gain patent protection. ${ }^{18}$ Unfortunately, the court never explained what, exactly, would be "enough." Since many patents involve unpatentable concepts to some extent, Mayo exposed a host of seemingly uncontroversial patents, including many software patents, to attacks on patent-eligibility grounds. ${ }^{19}$

The Supreme Court used a kind of point-of-novelty analysis in Mayo by focusing on what limitations were added to the law of nature at the heart of Prometheus' patents. ${ }^{20}$ This hearkens back to the reasoning used years ago in Parker v. Flook. ${ }^{21}$ In Flook, the Supreme Court treated the unpatentable formula that lay at the heart of Flook's patent as if it were in the prior art. ${ }^{22}$ But once that determination had been made, the application did not contain any patentable invention and the Court concluded that it did not cover patent-eligible subject matter. ${ }^{23}$ However, the Court later rejected this approach in Diamond $v$. Diehr when it said that "[i]n determining the eligibility

15. Bernard Chao, Moderating Mayo, 107 Nw. U. L. REV. 423 (2012).

16. Diamond v. Diehr, 450 U.S. 175, 185 (1981).

17. Mayo Collaborative Servs. v. Prometheus Labs., Inc., 132 S. Ct. 1289, 1293-94 (2012).

18. Id. at 1297 (emphasis omitted).

19. Michael J. Malecek \& Kenneth M. Maikish, The Prometheus Effect on Software Patents, 24 No. 6 Intell. Prop. \& TECH. L.J. 3, 3, 7 (2012) (arguing that the reasoning in Mayo suggests that software patents containing a mental step are not directed towards patentable subject matter); Tony Dutra, Computer, Medical Diagnostics, Gene Patents At Risk in Light of Mayo, Panelists Contend, Pat., Trademark \& Copyright L. Daily (Apr. 4, 2012) ("Intel's Tina] Chappell predicted that the court would view the algorithms that are typically cited in software patents in the same way that it analyzed the law of nature in medical diagnostics in Mayo.").

20. See infra text accompanying notes 113-23.

21. Parker v. Flook, 437 U.S. 584, 590 (1978).

22. Id. at 594 .

23. Id. at 594-95. 
... for patent protection under $\int 101, \ldots$ claims must be considered as a whole." ${ }^{24}$

In an earlier essay, Moderating Mayo, I argued that Mayo should be interpreted as reviving a point-of-novelty approach. ${ }^{25}$ Although the Mayo decision clearly reflected this perspective, the Supreme Court did not provide any test for lower courts to apply. My essay filled this void by offering a point-of-novelty test different from the rejected Flook test. This new pointof-novelty test follows from both Diehr and Mayo by considering the point of novelty in the context of the claim as a whole. ${ }^{26}$ Assuming that an otherwise unpatentable concept lies at the patent's point of novelty, this two-part test explains when other claim limitations add "enough" to the unpatentable concept to make it patent-eligible. ${ }^{27}$

Although I previously explained how my test applied to different variations of the medical diagnostics technology found in Mayo, ${ }^{28} \mathrm{I}$ have not explained how it would apply to software patents. The revised point-ofnovelty approach can also work in this context. The point of novelty of many software patents is a mathematical formula or abstract idea. ${ }^{29}$ In an attempt to minimize patent eligibility concerns, patent attorneys typically draft software claims so that the idea is connected to a physical device. ${ }^{30}$ Under the new point-of-novelty approach, that tactic should only be effective for certain kinds of patents. Some of the ideas underlying software patents are bound together with the physical components; for example, when a patent claims a novel algorithm for curing rubber products, both the formula and the physical components are necessary to accomplish the invention's goals. ${ }^{31}$ Without the physical device, the formula could not achieve the goal of the invention. Moreover, it makes no sense to discuss the formula apart from the physical devices used to implement it. Thus, there is a sufficiently strong

24. Diamond v. Diehr, 450 U.S. 175, 188 (1981).

25. Chao, supra note 15 , at 432-33.

26. Id. at 436 .

27. Id.; see infra text accompanying note 182 (discussing the basic modified point-ofnovelty test).

28. Chao, supra note 15 , at $436-40$.

29. Mathematical formulas are a type of law of nature that has frequently arisen in software patent cases. See, e.g., Diehr, 450 U.S. at 187; Parker v. Flook, 437 U.S. 584, 590 (1978); Gottschalk v. Benson, 409 U.S. 63, 71 (1972). In addition, many of the recent disputes before the Federal Circuit have centered on abstract ideas. See infra text accompanying notes 93-98 and 139-63.

30. See infra note 186.

31. See infra Part II. 
nexus between the idea and the device such that the subject matter should be patent-eligible. ${ }^{32}$

However, in many other cases, the idea underlying the software patent lacks a strong nexus to the device. ${ }^{33}$ One example of such a patent is the method for administering life insurance values claimed in Bancorp Services. ${ }^{34}$ Although the drafting of the patent attempts to establish a connection to a computer, one is not actually required; the idea of administering life insurance policy values makes perfect sense standing alone. ${ }^{35}$ Thus, the nexus between the physical components and the idea is weak. In such cases, attaching the idea to a machine should not be enough to make the concept patentable.

The rubber-curing and life insurance policy administration examples illustrate that the key to determining whether a software patent covers eligible subject matter is assessing the strength of the nexus between the patent's point of novelty and the physical devices found in the other claim limitations. Bits and pieces of this theory are scattered throughout both Supreme Court and Federal Circuit precedent, ${ }^{36}$ but neither court has fully appreciated the point-of-novelty approach to subject matter patent eligibility. When the approach is finally appreciated, patent law will finally have a practical tool for distinguishing questionable business method patents from other kinds of more deserving industrial software patents. ${ }^{37}$

In Part II, this Article describes the different types of software patents. At one end of the spectrum are software patents that are little more than business method patents. An example is the controversial Amazon one-click patent (click only once to buy). ${ }^{38}$ Business method software patents have been the subject of intense criticism and are often thought to burden innovation. At the other end of the spectrum are industrial software patents. From a policy perspective, these patents are indistinguishable from other

32. See Diehr, 450 U.S. at 191-93.

33. See infra Sections III.A, III.C.

34. Bancorp Servs. v. Sun Life Assurance Co., 687 F.3d 1266, 1279 (Fed. Cir. 2012) ("[T] he claims merely employ computers to track, reconcile, and administer a life insurance policy with a stable value component-i.e., the computer simply performs more efficiently what could otherwise be accomplished manually.").

35. See id. at 1275.

36. See infra text accompanying notes 187-88.

37. As Brian Love suggests, this may be the "least bad" option for dealing with problematic software patents. Brian J. Love, Why Patentable Subject Matter Matters for Software, 81 GeO. Wash. L. ReV. Arguendo 1, 8-11 (2012).

38. David Orozco, Administrative Patent Levers, 117 PENN. ST. L. REV. 1, 22-23 n.119 (2012) (discussing Free Software Foundation's boycott in response to Amazon's assertion of the one-click patent). 
industrial patents that are not implemented through software and these patents have not been subject to the same criticism as their business method cousins.

In Part III, this Article describes the two most recent Supreme Court decisions on patent-eligible subject matter, Bilski ${ }^{39}$ and Mayo, ${ }^{40}$ and the subsequent Federal Circuit decisions on software patents. Bilski is important for two reasons. First, it endorsed (for the most part) the machine-ortransformation test the Federal Circuit had previously adopted. ${ }^{41}$ Second, although Bilski did not categorically reject business method patents, the decision demonstrated a strong hostility towards them. ${ }^{42}$ Mayo is important because the Supreme Court took a new tack and looked at subject matter eligibility determinations from a point-of-novelty perspective. $^{43}$ Unfortunately, these decisions have not yielded any clarity for software patents. As Part III describes, different Federal Circuit panels have applied different tests for determining when software patents are drawn to eligible subject matter.

In Part IV, this Article describes the new point-of-novelty test that I offered in my earlier work and explains how the test can be applied to software patents. More specifically, my test concludes that software patents are drawn to patent-eligible subject matter when the physical limitations (e.g., rubber molding machines) are bound together with — and necessary to - the unpatentable concepts that lie at the patent's point of novelty. To be clear, I do not suggest that this view is the one I would take if I were given a clean slate. Others have already proposed idealized solutions. ${ }^{44}$ But patent applicants, examiners, litigants, and the lower courts need greater clarity now. ${ }^{45}$ The goal of this Article is to find a realistic path out of the current morass. Thus, the test described here is intended to be a practical solution that works within the constraints of current Supreme Court jurisprudence, satisfiying that jurisprudence in two important respects. First, the test should

39. Bilski v. Kappos, 130 S. Ct. 3218 (2010).

40. Mayo Collaborative Servs. v. Prometheus Labs., Inc., 132 S. Ct. 1289 (2012).

41. See Bilski, 130 S. Ct. at 3221.

42. See id. at 3257.

43. See Mayo, 132 S. Ct. at 1304.

44. See, e.g., Mark A. Lemley, Michael Risch, Ted M. Sichelman \& R. Polk Wagner, Life After Bilski, 63 STAN. L. REV. 1315, 1339-41 (2011) (proposing five factors for a scopebased \101 determination); Kevin Emerson Collins, Bilski and the Ambiguity of "An Unpatentable Abstract Idea," 15 LEWIS \& CLARK L. REV. 37 (2011) (proposing a more precise framework for the exclusion of abstract ideas from patent eligibility).

45. See CLS Bank III, 717 F.3d 1269, 1314 (Fed. Cir. 2013) (Moore, J., dissenting in part) (noting that many other cases dealing with the patent eligibility of software patents are pending in the Federal Circuit and district courts). 
achieve the Supreme Court's desired results by eliminating most business method software patents while retaining industrial software patents. Second, the test also operates within the Supreme Court's theoretical framework by applying a point-of-novelty approach.

Finally, Part V is a "postscript" that describes the latest morass created by the Federal Circuit in CLS Bank. The decision contains at least three different analytical approaches. This Article labels the two primary approaches as the "strong view" and "weak view" of $\ 101$ 's patent eligibility requirement. There is also a third approach advocated by Judge Newman alone that would substantially abandon the use of $\int 101$ to determine patent eligibility. Part V explains how the strong view is the only approach that faithfully follows the recent Supreme Court decisions. The two other approaches either implicitly (in the case of the weak view) or explicitly (in Judge Newman's opinion) reject the path the Supreme Court has taken. Assuming that the Supreme Court will not suddenly reverse itself, Part V explains why the point-of-novelty approach described here provides more clarity than the strong view.

\section{CATEGORIES OF SOFTWARE PATENTS}

Numerous commentators have been critical of software patents, arguing that software patents discourage innovation, ${ }^{46}$ have unclear boundaries, ${ }^{47}$ and are of low quality. ${ }^{48}$ According to a recent empirical study, software patents include some of the most litigated patents, but on the whole are much less

46. E.g., Federal Trade Commission, To Promote Innovation: The Proper Balance of Competition AND PATENT LAW AND POlicy 56 (2003), available at http://www.ftc.gov/os/2003/10/innovationrpt.pdf ("Many panelists and participants expressed the view that software and Internet patents are impeding innovation."); $c f$. Stuart J.H. Graham, Robert P. Merges, Pam Samuelson \& Ted Sichelman, High Technology Entrepreneurs and the Patent System: Results of the 2008 Berkeley Patent Survey, 24 BERKELEY TECH. L.J. 1255, 1262, 1289-90 (2009) (finding in a survey of start-up companies that (1) the first mover advantage, not patent protection, was the most "important" means to "capture competitive advantage" in the software industry; and (2) the majority of start-up companies in the software industry hold no patents at all).

47. E.g., Peter S. Menell, A Method for Reforming the Patent System, 13 MiCH. TELECOMM. \& TECH. L. REV. 487, 505-06 (2007) ("The boundaries of software and business method patents are inherently ambiguous.”).

48. E.g., Love, supra note 37, at 8-9 (arguing that examiners allow "many overbroad software applications to issue as patents”). But see John R. Allison \& Ronald J. Mann, Disputed Quality of Software Patents, 85 WASH. U. L. REV. 297 (2007) (discussing an empirical study which suggests that, with respect to disclosure of prior art, the quality of software patents is not worse than the quality of patents in other fields). 
likely than other types of patents to be found valid and infringed. ${ }^{49}$ This suggests that software patents take up disproportionate litigation resources, while offering only a slight benefit in return. ${ }^{50}$ This may be because software patents are one of the weapons of choice for non-practicing patent entities. ${ }^{51}$ Commentators have widely criticized the many patent lawsuits brought by non-practicing entities for focusing resources on litigation instead of innovation. ${ }^{52}$ In 2011, Congress even enacted a temporary program for challenging the validity of business method patents. ${ }^{53}$

While these criticisms of software patents as a category are valid in some cases, there are many different kinds of software patents. ${ }^{54}$ One kind is the business method patent. Business method patents like those in CLS Bank (covering a trading system platform for exchanging obligations) ${ }^{55}$ and Bancorp Services (covering a system for administering and tracking life insurance values) lie at the heart of the controversy. ${ }^{56}$ Many of the claims in both cases explicitly contained computer-based limitations or have been interpreted to

49. John R. Allison, Mark A. Lemley \& Joshua Walker, Patent Quality and Settlement Among Repeat Patent Litigants, 99 GEO. L.J. 677, 707-08 (2011).

50. Id. at 708 .

51. Brian J. Love, An Empirical Study of Patent Litigation Timing: Could a Patent Term Reduction Decimate Trolls Without Harming Innovators?, 161 U. PA. L. REV. 1309, 1343 (2013) (finding that about $40 \%$ of assertions by non-practicing entities were brought to enforce software patents).

52. See, e.g., President's Council of Economic Advisers, the National Economic Council, and the Office of Science \& Technology Policy, Patent Assertion and U.S. Innovation 5 (2013), available at http://www.whitehouse.gov/sites/default/files/docs/patent_report.pdf (discussing the relationship between patent assertion entities and software patents); Ted Sichelman, Commercializing Patents, 62 STAN. L. REV. 341, 368 (2010) (saying that nonpracticing entities stifle commercialization of patented inventions by "exploit[ing] litigation and licensing market defects to extract unwarranted rents").

53. Pub. L. No. 112-29, \18, 125 Stat. 284, 329-31 (2011).

54. Compare Allison \& Mann, supra note 48, at 308-09 (defining a software patent broadly as "one in which at least one claim element covers data processing - that is, the act of manipulating data-regardless of whether the code carrying out that data processing is on a magnetic storage medium or embedded in a chip"), with Stuart J.H. Graham \& David C. Mowery, Intellectual Property Protection in the U.S. Software Industry, in PATENTS IN THE Knowledge-BAsed Economy 219, 232 (Wesley M. Cohen \& Stephen A. Merrill, eds., Committee on Intellectual Property Rights in the Knowledge-Based Economy, National Research Council, 2003) (identifying software patents based on the industry characteristics; this results in a narrower set).

55. Terry Baynes, Federal Circuit finds business method patentable, THOMSON REUTERS NEWS \& INSIGHT, July 9, 2012, available at http://newsandinsight.thomsonreuters.com/ New_York/News/2012/07_-_July/Federal_Circuit_finds_business_method_patentable (describing the patents in CLS Bank as business method patents).

56. CLS Bank I, 685 F.3d 1341, 1343 (Fed. Cir. 2012), reh'g en banc granted, opinion vacated, 484 F. App'x 559 (Fed. Cir. 2012), aff'd en banc, 717 F.3d 1269 (Fed. Cir. 2013); Bancorp Servs. v. Sun Life Assurance Co., 687 F.3d 1266, 1269 (Fed. Cir. 2012). 
require implementation on a computer. ${ }^{57}$ The true focus of these patents, however, is on the business method itself.

Another kind of software patent is the industrial method patent. ${ }^{58}$ For example, the patents in both Parker v. Flook ${ }^{59}$ and Diamond v. Diehr ${ }^{60}$ used new algorithms in industrial applications. In Flook, the claims involved a formula for calculating an alarm limit for a catalytic chemical conversion of hydrocarbons. ${ }^{61}$ The patent in Diehr used a mathematical equation to develop a new process for molding and curing raw rubber into products. ${ }^{62}$ Both patents were implemented with software. ${ }^{63}$

Of course, not every software patent can be easily classified as either a business method patent or an industrial patent. Some patents, for instance, operate solely on computers, like most business method software patents, but also improve the performance of a physical machine (i.e., the computer), like most industrial software patents. The patents in Research Corporation Technologies, Inc. v. Microsoft fall within this middle ground. ${ }^{64}$ The patents in that case covered a particular method of digital image halftoning, which allowed computers to present many shades and color tones using only a limited number of pixel colors. ${ }^{65}$ The claims did not require any physical device other than a computer. This might suggest that the patents were business method software patents. However, the technology was used to improve images displayed on printers and displays. ${ }^{66}$ Thus, they could also be thought of as industrial software patents. Ultimately, any rule the Federal Circuit issues concerning patentable subject matter must be able to address all types of software patents, including those that do not fit easily into a discrete category.

57. CLS Bank I, 685 F.3d at 1344; Bancorp Servs., 687 F.3d at 1271.

58. There is similar concept in Europe where such software patents are said to have "technical effect." See Patrick E. King, Ryan M. Roberts \& Andrew V. Moshirnia, The Confluence of European Activism and American Minimalism: Patentable Subject Matter After Bilski, 27 SANTA Clara COMPUTER \& High TECH. L.J. 247, 258-59 (2011) (discussing interpretations of patentability requirements under Article 52 of the European Patent Convention).

59. Parker v. Flook, 437 U.S. 584, 585 (1978).

60. Diamond v. Diehr, 450 U.S. 175, 187 (1981).

61. Flook, 437 U.S. at 585.

62. Diehr, 450 U.S. at 187.

63. Flook, 437 U.S. at 586; Diehr, 450 U.S. at 177.

64. Research Corp. Techs. Inc., v. Microsoft Corp., 627 F.3d 859, 862-63 (Fed. Cir. 2010).

65. Id. This technology is used to enhance the images found on computer displays and printers.

66. Notably, the claims at issue did not actually require the printers or display devices. See, for example, claim 1 of the '310 patent. $I d$. at 865 . 
There are a variety of reasons why many of the criticisms of software patents generally do not apply well to industrial software patents. First, the boundaries of these patents are not as amorphous as those of many business method software patents because the scopes of most industrial software patents are tied to particular applications. ${ }^{67}$ Second, conventional wisdom suggests that the non-practicing entity problem is greater with respect to business method patents than to industrial software patents. ${ }^{68}$ Third, many of the critiques of software patents focus on patents held by software companies; these companies, however, typically do not hold industrial software patents. ${ }^{69}$

As a practical matter, the Federal Circuit was unlikely to declare in its en banc review of CLS Bank that industrial software patents are per se ineligible. Such a rule would disturb the settled expectations of too many industries that rely on industrial software patents to protect their intellectual property rights. ${ }^{70}$ Additionally, a decision eliminating industrial software patents could violate the United States' obligations under international law. ${ }^{71}$ Thus, the only real question on the table for the Federal Circuit in CLS Bank was whether to rule that some software patents are ineligible even when the claims tie the

67. Even the Supreme Court has expressed concern about "vagueness and suspect validity of some of these [business method] patents." eBay Inc. v. MercExchange LLC, 547 U.S. 388, 396 (2006) (Kennedy, J., concurring).

68. See Orozco, supra note 38, at 15-23 (discussing the problem of business method patent assertions by non-practicing entities). But see Michael Risch, Patent Troll Myths, SETON HALL L. REV. 457, 477 (2012) (suggesting that "business methods are a relatively small part of NPE litigation, perhaps smaller than conventional wisdom might assume”).

69. This is not surprising given how software patents are classified. See Graham et al., supra note 46, at 1268-69 n.41, $1271 \mathrm{n} .46$ (selecting primarily software companies for the authors' survey sample). In a different article, Graham and Mowery define software patents to actually exclude "embedded software" that is directly incorporated into a product and whose operation is typically not controlled by the user. Graham \& Mowery, supra note 54, at 235-36. Of course these are typically industrial software patents.

70. Festo Corp. v. Shoketsu Kinzoku Kogyo Kabushiki Co., 535 U.S. 722, 739 (2002) (explaining that a fundamental change to patent law could "risk destroying the legitimate expectations of inventors in their property").

71. See Eric Keller, Time-Varying Compulsory License: Facilitating License Negotiation for Efficient Post-Verdict Patent Infringement, 16 TEX. INTELL. PROP. L.J. 427, 439 ("Solutions that discriminate in the protection of patent rights based on 'field of technology' may also run afoul of treaty obligations under TRIPS Article 27.1.”); Agreement on Trade-Related Aspects of Intellectual Property Rights, Apr. 15, 1994, Marrakesh Agreement Establishing the World Trade Organization, Annex 1C, Legal Instruments-Results of the Uruguay Round vol. 31, 33 I.L.M. 1197 (1994) (subject to certain permissible exceptions, "patents shall be available for any inventions, whether products or processes, in all fields of technology, provided that they are new, involve an inventive step, and are capable of industrial application"). 
software to a computer. Unfortunately, the splintered decision provided no helpful guidance whatsoever. ${ }^{72}$

The point-of-novelty approach described in Part IV naturally distinguishes between industrial and business method patents and offers a framework that suggests that most business method software patents are ineligible for patent protection. The proposal is not intended to be an ideal solution divorced from reality. Rather, it draws upon existing concepts found in both Supreme Court and Federal Circuit precedent to create a test for patent eligibility that meets the goals of the courts and commentators alike. But before providing the details of this approach, Part III describes how recent case law has addressed subject matter patent eligibility, particularly as applied to software patents.

\section{THE FRACTURED JURISPRUDENCE}

The two most recent Supreme Court cases on subject matter patent eligibility place very different constraints on how the Federal Circuit must think about software patents. Bilski offers the machine-or-transformation test as one possible test for analyzing subject matter patent eligibility. ${ }^{73}$ But just as importantly, Bilski shows a strong hostility towards business method patents, albeit for different reasons. ${ }^{74}$ In contrast, Mayo says nothing about business method patents, but offers an entirely different analytical approach, which implicitly requires a point-of-novelty framework. ${ }^{75}$ The decision from the Federal Circuit in CLS Bank had to account for these two different strands of thinking.

\section{A. BILSKI V.KAPPOS}

In Bilski, the Supreme Court evaluated the patent eligibility of a procedure for instructing buyers and sellers on how to protect against the risk of price fluctuations in a discrete section of the economy. ${ }^{76}$ Although the Court unanimously concluded that Bilski's claims did not cover patenteligible subject matter, there was significant disagreement about how to reach that conclusion.

The Court considered two proposed limitations under $\int 101$ : the machine-or-transformation test and the categorical exclusion of business method patents. Writing the opinion of the Court, Justice Kennedy first

72. See infra Part V (discussing the different opinions from CLS Bank Int'l v. Alice Corp.).

73. Bilski v. Kappos, 130 S. Ct. 3218, 3227 (2010).

74. See id. at 3228-29.

75. Mayo Collaborative Servs. v. Prometheus Labs., Inc., 132 S. Ct. 1289 (2012).

76. Bilski, 130 S. Ct. at 3223-24. 
addressed the machine-or-transformation test. $^{77}$ The underlying Federal Circuit decision had held that the machine-or-transformation test was the sole test for determining the patentability of a "process" under $\int 101 .^{78}$ In other words, a process was only patentable if it was tied to a particular machine or transformed an article to another state. ${ }^{79}$ The Supreme Court decision modified that holding, finding that the machine-or-transformation test may be "a useful and important clue" or "investigative tool," but it is "not the sole test for deciding whether an invention is a patent-eligible 'process'" under $\int 101 .^{80}$

Speaking for only four members of the Court, Justice Kennedy's opinion recognized that it was unclear how the machine-or-transformation test might apply to software patents. ${ }^{81}$ On the one hand, " $[t]$ he machine-ortransformation test may well provide a sufficient basis for evaluating processes similar to those in the Industrial Age-for example, inventions grounded in a physical or other tangible form." 82 On the other hand, Justice Kennedy recognized that the machine-or-transformation test "would create uncertainty as to the patentability of software, advanced diagnostic medicine techniques, and inventions based on linear programming, data compression, and the manipulation of digital signals." ${ }^{\prime 83}$ In fact, Justice Kennedy went out of his way to say that he was "not commenting on the patentability of any particular invention, let alone holding that any of the above-mentioned technologies from the Information Age should or should not receive patent protection." 84

While the entire Court agreed that the machine-or-transformation test was not an exclusive test, the justices differed sharply on the eligibility of business method patents. The majority held that $\int 101$ does not categorically exclude business method patents. ${ }^{85}$ Indeed, the opinion questioned whether there was even a common understanding of the term "business method patents." ${ }^{\prime 86}$ Four members of the Court disagreed, arguing that business

77. Justices Roberts, Thomas, and Alito joined the opinion in full while Justice Scalia only joined part of the opinion. $I d$. at 3223.

78. In re Bilski, 545 F.3d 943, 954 (Fed. Cir. 2008) (en banc).

79. Id. at 956.

80. Bilski, 130 S. Ct. at 3227.

81. Justice Scalia did not join in this part of Justice Kennedy's opinion. Id. at 3223.

82. Id. at 3227.

83. Id.

84. Id. at 3228 .

85. Id. at 3227. Justices Roberts, Thomas, Alito and Scalia joined Justice Kennedy in this part of the opinion. Id. at 3223.

86. See id. at 3228 ("Nor is it clear how far a prohibition on business method patents would reach, and whether it would exclude technologies for conducting a business more 
methods are categorically unpatentable. Relying chiefly on a lengthy historical analysis, Justice Stevens, joined by Justices Ginsburg, Breyer, and Sotomayor, argued that Bilski's 'method is not a 'process' [under \$101] because it describes only a general method of engaging in business transactions - and business methods are not patentable." ${ }^{87}$ Although Stevens did not define what a business method patent was, his opinion provided plenty of examples, including insuring against loss by bad debt, a method of abbreviating rail tariff schedules, the cafeteria system for transacting a restaurant business, and a diaper service. ${ }^{88}$

After Bilski, it appeared that business method patents had survived, but just barely. Four Justices would have categorically excluded business method patents. ${ }^{89}$ Moreover, even Justice Kennedy's opinion explicitly left the door open for further restrictions on business method patents. ${ }^{90}$ Since most business method patents fall within the category of software patents, ${ }^{91}$ it is not surprising that the Federal Circuit has given software patents more scrutiny.

Soon after Bilski, the Federal Circuit issued three inconsistent decisions on the patent eligibility of business method software patents. In Ultramercial $v$. Hulu, the court faced a $\int 101$ challenge to a patent claiming "a method for distributing copyrighted products (e.g., songs, movies, books) over the Internet." 92 The decision characterized the underlying idea as using advertising as currency. ${ }^{93}$ This idea was admittedly abstract, but the Federal Circuit noted that the claimed steps were "likely to require intricate and

efficiently."); see, e.g., Bronwyn H. Hall, Business and Financial Method Patents, Innovation, and Policy, 56 SCOT. J. POL. ECON. 443, 445 (2009) ("There is no precise definition of business method patents.").

87. Bilski, 130 S. Ct. at 3232.

88. Id. at 3246-48.

89. Id. at 3257 .

90. Id. at 3231. The Court stated:

It may be that the Court of Appeals thought it needed to make the machine-or-transformation test exclusive precisely because its case law had not adequately identified less extreme means of restricting business method patents ... . In disapproving an exclusive machine-ortransformation test, we by no means foreclose the Federal Circuit's development of other limiting criteria that further the purposes of the Patent Act and are not inconsistent with its text.

Id.

91. James Bessen \& Michael J. Meurer, Patent Failure: How Judges, BUREAUCRATS, AND LAWYERS PUT INNOVATORS AT RISK 187 (2008).

92. Ultramercial, LLC v. Hulu, LLC, 657 F.3d 1323 (Fed. Cir. 2011), vacated sub nom., Wildtangent, Inc. v. Ultramercial, LLC, 132 S. Ct. 2431 (2012).

93. Id. at $1328,1330$. 
complex computer programming" and could only be performed on the Internet. ${ }^{94}$ The court held that because all the claims connected the underlying concept to a computer or the Internet, they were patent eligible. ${ }^{95}$

But two other decisions arrived at very different results. In CyberSource v. Retail Decisions, the Federal Circuit found that a patent related to a "method and system for detecting fraud in a credit card transaction between [a] consumer and a merchant over the internet" was not patent eligible. ${ }^{96}$ The Federal Circuit reasoned that the ideas underlying the software claims were not sufficiently connected with their computer-based limitations to satisfy the machine-or-transformation test. ${ }^{97}$ The Federal Circuit in Dealertrack v. Huber also suggested that adding computer limitations to a claim would not render every concept patent eligible. ${ }^{98}$ In Dealertrack, the patents related to a computer-aided method and system for processing credit applications over electronic networks. ${ }^{99}$ Even though some of the claims explicitly required the Internet, the Federal Circuit found that this recitation was insufficient because "the claims ... recite[d] only that the method is 'computer aided' without specifying any level of involvement or detail." 100 Moreover, the court concluded that the claims preempted a fundamental concept. ${ }^{101}$ Thus, Dealertrack appeared to expand the potential grounds for rejecting a software patent on subject matter patent eligibility grounds.

These decisions could be interpreted to suggest that software patents are drawn to eligible subject matter when the computer limitations are more complex, or simply have more steps. Indeed, a comparison of the central claims in these cases shows that CyberSource struck down a claim with three computer steps, ${ }^{102}$ while Ultramercial upheld a claim with eleven computer

94. Id. at 1328 .

95. $I d$.

96. CyberSource Corp. v. Retail Decisions, Inc., 654 F.3d 1366, 1367 (Fed. Cir. 2011).

97. Id. at 1375 .

98. See Dealertrack, Inc. v. Huber, 674 F.3d 1315, 1333 (Fed. Cir. 2012).

99. Id. at 1317.

100. Id. at 1334.

101. See id. at 1333 ("Neither Dealertrack nor any other entity is entitled to wholly preempt the clearinghouse concept.").

102. CyberSource Corp. v. Retail Decisions, Inc., 654 F.3d 1366, 1370 (Fed. Cir. 2011). Claim 3 recites:

A method for verifying the validity of a credit card transaction over the Internet comprising the steps of: a) obtaining information about other transactions that have utilized an Internet address that is identified with the [] credit card transaction; b) constructing a map of credit card numbers based upon the other transactions and; c) utilizing the map of credit card numbers to determine if the credit card transaction is valid.

Id. 
steps. ${ }^{103}$ But making subject matter eligibility determinations based on how many detailed (and often inconsequential) steps a patent attorney can draft makes little sense. Most observers simply viewed the decisions as inconsistent. ${ }^{104}$ Thus, Bilski did not result in any clarity for standards of patentability for software. ${ }^{105}$ Mayo was decided immediately on the heels of

103. Ultramercial, LLC v. Hulu, LLC, 657 F.3d 1323, 1324-25 (Fed. Cir. 2011) (discussing claim 1 of the ' 545 patent). Claim 1 recites:

A method for distribution of products over the Internet via a facilitator, said method comprising the steps of: a first step of receiving, from a content provider, media products that are covered by intellectual property rights protection and are available for purchase, wherein each said media product being comprised of at least one of text data, music data, and video data; a second step of selecting a sponsor message to be associated with the media product, said sponsor message being selected from a plurality of sponsor messages, said second step including accessing an activity $\log$ to verify that the total number of times which the sponsor message has been previously presented is less than the number of transaction cycles contracted by the sponsor of the sponsor message; a third step of providing the media product for sale at an Internet website; a fourth step of restricting general public access to said media product; a fifth step of offering to a consumer access to the media product without charge to the consumer on the precondition that the consumer views the sponsor message; a sixth step of receiving from the consumer a request to view the sponsor message, wherein the consumer submits said request in response to being offered access to the media product; a seventh step of, in response to receiving the request from the consumer, facilitating the display of a sponsor message to the consumer; an eighth step of, if the sponsor message is not an interactive message, allowing said consumer access to said media product after said step of facilitating the display of said sponsor message; a ninth step of, if the sponsor message is an interactive message, presenting at least one query to the consumer and allowing said consumer access to said media product after receiving a response to said at least one query; a tenth step of recording the transaction event to the activity $\log$, said tenth step including updating the total number of times the sponsor message has been presented; and an eleventh step of receiving payment from the sponsor of the sponsor message displayed.

Id.

104. See, e.g., Recent Case, CyberSource Corp. v. Retail Decisions, Inc., 654 F.3d 1366 (Fed. Cir. 2011), 125 HARv. L. ReV. 851, 857 (2012) (noting that the Ultramercial court's attempt to distinguish Cybersource seems forced); Kelly J. Kubasta, Litigation Affecting Five Key Patent Law Areas, in InTellectual Property Law 2012 57, 62 (Eddie Fournier ed., 2012) ("Unfortunately, the result of CyberSource and Ultramercial is quite unclear and it remains uncertain as to where the line will be drawn as to software and methods as patent-eligible subject matter.").

105. See N. Scott Pierce, A Great Invisible Crashing: The Rise And Fall Of Patent Eligibility Through Mayo v. Prometheus, 23 Fordham InTEll. Prop. Media \& EnT. L.J. 186, 189-90

(2012) ("[T]here is little to guide ... Federal Circuit cases that have issued since Bilski and 
CyberSource, Ultramercial, and Dealertrack. Ideally, the Supreme Court would have addressed the Federal Circuit's conflicting case law and provided a framework for making subject matter eligibility determinations, particularly in the area of software patents. Unfortunately, Mayo just created more confusion.

\section{B. MaYo V. PROMETheus}

Although the technology in Mayo related to medical diagnostic testing, ${ }^{106}$ the approach the Court laid out has significant implications for software patents. ${ }^{107}$ The inventors of Prometheus' claimed methods discovered a specific correlation between the levels of metabolized drug in the body and the optimal drug dosage. ${ }^{108}$ Two patents were issued on this discovery, both claiming a method for determining the level of the metabolized drug in a subject and informing a doctor to adjust the dosage within specific parameters. ${ }^{109}$ The defendants argued that the claims were not drawn to patent-eligible subject matter as required by $\$ 101$, and this issue eventually made its way to the Supreme Court. ${ }^{110}$

A unanimous Court held that Prometheus' claims were not patent eligible. ${ }^{111}$ The decision first noted that "Prometheus' patents set forth laws of nature-namely, relationships between concentrations of certain metabolites in the blood and the likelihood that a dosage of a thiopurine drug will prove ineffective or cause harm."112 Accordingly, the Supreme Court framed the question by asking, "do the patent claims add enough to their statement of the correlations to allow the processes they describe to qualify as patent-eligible processes that apply natural laws?"113

Relying on an examination of each of the claimed limitations, the Supreme Court answered its own question by saying "no." "The decision first examined a step of "administering" the particular drug. ${ }^{115}$ According to the Court, this step simply limited the use of the correlation to the relevant

the Supreme Court's apparent encouragement to lower courts to continue to develop new tests of patent eligibility reflect a continuing potential for confusion.").

106. Mayo Collaborative Servs. v. Prometheus Labs., Inc., 132 S. Ct. 1289, 1293 (2012).

107. Indeed, the Supreme Court vacated Ultramercial and remanded it to the Federal Circuit in light of Mayo. WildTangent, Inc. v. Ultramercial, LLC, 132 S. Ct. 2431 (2012).

108. Mayo, 132 S. Ct. at 1295.

109. Id.

110. Id.

111. Id. at 1304 .

112. Id. at 1296.

113. Id. at 1297.

114. Id.

115. Id. 
audience: doctors. ${ }^{116}$ Since limiting the use of an abstract idea to a particular technological environment cannot circumvent the prohibition against patenting abstract ideas, that step did not render the claims patentable. ${ }^{117}$ Second, the Court examined two "wherein" limitations that noted the correlation between particular drug metabolite levels and a need to change the dosage. ${ }^{118}$ The Court characterized these limitations as "simply tell[ing] a doctor about the relevant laws, at most adding a suggestion that he should take those laws into account when treating his patient." "The decision said nothing more on the topic, apparently indicating that these limitations clearly could not change an unpatentable concept into a patentable application. Third, the decision turned to the step of "determining" the level of the drug's metabolite in the body. ${ }^{120}$ This step was well known in the prior art. ${ }^{121}$ Since conventional or obvious pre-solution activity is not normally sufficient to transform an unpatentable law of nature into a patent-eligible application, the Court disregarded this step as well. ${ }^{122}$ The Court concluded that none of the limitations, individually or in combination, were sufficient "to transform the nature of the claim." 123 In short, the Supreme Court determined that three types of limitations do not make an unpatentable idea patent eligible: (1) limiting an unpatentable concept to a particular audience, (2) telling someone about the concept, or (3) adding a conventional or obvious presolution activity. ${ }^{124}$

After determining that the claims did not add "enough" to the unpatentable idea at the heart of the invention, ${ }^{125}$ the Supreme Court pursued three additional lines of analysis that ostensibly corroborated its conclusion. I previously criticized these dicta because they are analytically weak and

116. Id.

117. Id. (citing In re Bilski, 545 F.3d 943, 962 (Fed. Cir. 2008)).

118. The Court quoted the following limitations:

[W] herein the level of 6 -thioguanine less than about $230 \mathrm{pmol}$ per $8 \times 10^{8}$ red blood cells indicates a need to increase the amount of said drug subsequently administered to said subject and wherein the level of 6thioguanine greater than about 400 pmol per $8 \times 10^{8}$ red blood cells indicates a need to decrease the amount of said drug subsequently administered to said subject.

Id. at 1295 (citing U.S. Patent No. 6,355,623 col.20 11.10-20 (filed Apr. 8, 1999)).

119. Id. at 1297.

120. Id. at $1297-98$.

121. Id.

122. Id.

123. Id.

124. Id.

125. Id. 
difficult to apply. ${ }^{126}$ I provide an abbreviated version of my critique here with a few refinements. First, the decision used two earlier Supreme Court decisions as guideposts, Parker v. Flook ${ }^{127}$ and Diamond v. Diehr, ${ }^{128}$ and suggested that Prometheus' claims were closer to the ineligible claims in Flook than the eligible claims in Diehr. ${ }^{129}$ These guideposts are problematic because - as many commentators have noted - the distinction between Flook and Diehr is unclear, and may be nonexistent. ${ }^{130}$ Both cases appear to apply a new formula to an industrial process. Even the Mayo Court appeared to have trouble explaining just why the additional steps in Diebr rendered its claims patent eligible. $^{131}$

Second, the Court said that simply appending general limitations to a concept is just like saying "apply it," and clearly is insufficient to render an unpatentable law of nature patent eligible. ${ }^{132}$ This line of inquiry is also troublesome. The complaint about general limitations appears disingenuous. The claims in Mayo were quite specific; they identified particular levels of particular drug metabolites that would indicate when the dosing should change. Thus, this line of inquiry really appears to be an unhelpful "know it when you see it" kind of analysis. ${ }^{133}$

Third, the Court said that Prometheus' claims were too broad and impermissibly tied up the future use of a law of nature. ${ }^{134}$ This issue is often framed as a question of preemption: Does the claim preempt all uses of the unpatentable concept (e.g., law of nature or abstract idea) ${ }^{135}$ But this preemption test can easily be manipulated. Almost any claim can be

126. Chao, supra note 15 , at 429-32.

127. Parker v. Flook, 437 U.S. 584 (1978).

128. Diamond v. Diehr, 450 U.S. 175 (1981).

129. Mayo, 132 S. Ct. at $1298-1300$.

130. See, e.g., Mark A. Lemley, Point of Novelty, 105 Nw. U. L. REV. 1253, 1278 (2011) (characterizing the claims in Diebr and Flook as "almost exactly parallel"); Kevin Emerson Collins, Propertizing Thought, 60 S.M.U. L. REV. 317, 349 (2007) ("Flook and Diehr are difficult to reconcile.").

131. Mayo, 132 S. Ct. at 1299 (only saying that "[t] hese other steps apparently added to the formula something that in terms of patent law's objectives had significance-they transformed the process into an inventive application of the formula." (emphasis added)).

132. Id. at 1300.

133. See CLS Bank Int'l v. Alice Corp., 685 F.3d 1341, 1348-52 (Prost, J., dissenting); see also infra text accompanying notes 148-49.

134. Mayo, 132 S. Ct. at 1301-02.

135. See id. at 1301; see, e.g., Bilski v. Kappos, 130 S. Ct. 3218, 3231 (2010) ("Allowing petitioners to patent risk hedging would pre-empt use of this approach in all fields, and would effectively grant a monopoly over an abstract idea.”); Diamond v. Diehr, 450 U.S. 175, 185 (1981) (stating that no one can patent "laws of nature, natural phenomena, and abstract ideas"). 
characterized as too broad if the concept is defined narrowly. ${ }^{136}$ Mayo provides a good example of this problem. The Supreme Court defined the natural laws at issue as "the relationships between the concentration in the blood of certain thiopurine metabolites and the likelihood that the drug dosage will be ineffective or induce harmful side-effects." ${ }^{\prime 137}$ However, the Court could have just as easily said that the natural law was the effect that thiopurine had on humans. Alternatively, the natural law could have been the understanding that a reduction in any drug dose leads to lower levels of the corresponding metabolite in the body. If the natural law were characterized in either of these fashions, the claims would have been drawn to one narrow application. In other words, the claims would not have preempted all applications of the natural law, suggesting that they were drawn to eligible subject matter.

Importantly, Mayo did not apply (or reject) the machine-ortransformation test, which had effectively emerged as the only test for determining patent eligibility after Bilski. ${ }^{138}$ Instead, the Supreme Court merely said "we have neither said nor implied that the [machine-ortransformation] test trumps the 'law of nature' exclusion. That being so, the test fails here." 139 The Court then proceeded to apply its new approach. By assessing whether a claim's limitations added "enough" to the law of nature that Prometheus' inventors had discovered, Mayo outlined another line of inquiry to examine. But that was not all. The three corroborating justifications provided even more fodder for the lower courts to chew upon. Given all these varied and difficult ways to assess patent eligibility, it is not surprising that there continued to be disagreement within the Federal Circuit.

\section{The Post-MAYO SPLIT}

CLS Bank International v. Alice Corp. ${ }^{140}$ was the first Federal Circuit decision to address the eligibility of software patents after Mayo. The central idea underlying the patents in CLS Bank related to exchanging obligations

136. See Tun-Jen Chiang, The Rules and Standards of Patentable Subject Matter, 2010 WIS. L. REV. 1353, 1369-71 (2010) (explaining how claims can be viewed at different levels of abstraction).

137. Mayo, 132 S. Ct. at 1294.

138. See Lemley et al., supra note 44, at 1316 ("[T]he U.S. Patent and Trademark Office (PTO), patent litigants, and district courts have all continued to rely on the machine-ortransformation test in the wake of Bilski: no longer as the sole rule, but as a presumptive starting point that threatens to become effectively mandatory.").

139. Mayo, 132 S. Ct. at 1303 (internal citations omitted).

140. CLS Bank I, 685 F.3d 1341 (Fed. Cir. 2012), reh'g en banc granted, opinion vacated, 484 F. App'x 559 (Fed. Cir. 2012), aff'd en banc, 717 F.3d 1269 (Fed. Cir. 2013). 
using a third party to eliminate risk. ${ }^{141}$ Although the patents contained both method and system claims, they all used a computer and the court said that the "form of the claim" did not change the patent eligibility analysis. ${ }^{142}$

Although the majority opinion in CLS Bank discussed the recent Supreme Court decision in Mayo, the decision had little impact on the rule the majority announced. ${ }^{143}$ Judge Linn, joined by Judge O'Malley, wrote: "[T] his court holds that when-after taking all of the claim recitations into consideration - it is not manifestly evident that a claim is directed to a patent ineligible abstract idea, that claim must not be deemed for that reason to be inadequate under $\int 101 . " 144$ But the "manifestly evident" language is not from Mayo or even from Bilski. It comes from Research Corp. Technologies $v$. Microsoft ${ }^{145}$ and Ultramercial v. Hulu, ${ }^{146}$ two Federal Circuit decisions that were decided prior to Mayo. The majority in CLS Bank interpreted the "manifestly evident" rule in an even more patent friendly way, stating that a claim is only drawn to unpatentable subject matter if "the single most reasonable understanding is that a claim is directed to nothing more than a fundamental truth or disembodied concept ...."147 Under this standard, it was easy for the Federal Circuit to find that Alice's patents covered patent-eligible subject matter.

CLS Bank does not follow Mayo's approach, which focuses on whether certain claim limitations add "enough" to the unpatentable abstract concept to render it patent eligible. ${ }^{148}$ To be fair, at the very end of the opinion, the majority paid lip service to Mayo by characterizing some claim limitations as being "integral" to the method, "playing a significant part in permitting the method to be performed."149 Judge Prost's dissent challenged these statements and argued that the majority did "not explain whether [the

141. Id. at 1343 .

142. Id. at 1353 .

143. See id. at $1348,1350-51$.

144. Id. at 1352 (emphasis added).

145. See Research Corp. Techs., Inc. v. Microsoft Corp., 627 F.3d 859, 868 (Fed. Cir. 2010) (stating that a "disqualifying characteristic should exhibit itself so manifestly as to override the broad statutory categories of eligible subject matter").

146. See Ultramercial, LLC v. Hulu, LLC, 657 F.3d 1323, 1327 (Fed. Cir. 2011) (citing Research Corp., 627 F.3d at 868), vacated sub nom. WildTangent, Inc. v. Ultramercial, LLC, 132 S. Ct. 2431 (2012).

147. CLS Bank I, 685 F.3d at 1352.

148. Judge Prost's dissent also noticed this problem and criticized the majority for failing to follow the Supreme Court's approach. CLS Bank I, 685 F.3d at 1357 (Prost, J., dissenting); see also Robert D. Swanson, Note, Section 101 and Computer-Implemented Inventions, 16 StAn. TECH. L. REV. 161, 166 (2012) (noting that a "manifestly abstract" test is inconsistent with both Bilski and Mayo).

149. CLS Bank I, 685 F.3d at 1355. 
additional limitations] should be characterized as such, and what 'integral' means in the context of $\int 101$ in the first place."150

Although the majority's statements were conclusory, the dissent's approach was hardly more illuminating. It provided a simplified description of the claims and found: "The claim in effect presents an abstract idea and then says 'apply it.' That is not enough." ${ }^{151}$ Although this construct is clearly found in Mayo, it is unhelpful. Both the majority and dissent believe that they know a claim directed at an unpatentable abstract idea when they see it, but they clearly see particular claims differently.

Two weeks after CLS Bank, the Federal Circuit decided Bancorp Services v. Sun Life, ${ }^{152}$ which only added to the confusion. In Bancorp, the patents covered both system and method claims for administering and tracking the values of life insurance policies in separate accounts. ${ }^{153}$ Some of the method claims did not have to be implemented on a computer while all the remaining claims did. Despite these differences, the Federal Circuit treated all the claims "as equivalent for purposes of patent eligibility under $\int 101 . " 154$

This time the Federal Circuit applied a variation of the Mayo approach that was specifically tailored to software patents. After reviewing the $\ 101$ jurisprudence, the court in Bancorp Services declared, "To salvage an otherwise patent-ineligible process, a computer must be integral to the claimed invention, facilitating the process in a way that a person making calculations or computations could not." 155

Applying this test, the Federal Circuit identified an unpatentable abstract idea underlying the claims_- "managing a stable value protected life insurance policy and then instructing the use of well-known calculations to help establish some of the inputs into the equation." claims also required a computer, the court found that "[ $t]$ he computer required by ... Bancorp's claims is employed only for its most basic function, the performance of repetitive calculations, and as such does not impose meaningful limits on the scope of those claims." "157 The Federal Circuit emphasized the limited role computers played in Bancorp's claim,

150. Id. at 1357 (emphasis omitted).

151. Id. at 1358 (citing Mayo Collaborative Servs. v. Prometheus Labs., Inc., 132 S. Ct. 1289, 1294 (2012)).

152. Bancorp Servs. v. Sun Life Assurance Co., 687 F.3d 1266 (Fed. Cir. 2012).

153. Id. at $1270-72$.

154. Id. at 1277.

155. Id. at 1278 (citing SiRF Tech., Inc. v. Int'l Trade Comm'n, 601 F.3d 1319, 1333 (Fed. Cir. 2010)).

156. Id. (citing Bilski v. Kappos, 130 S. Ct. 3218, 3231 (2010)) (brackets omitted).

157. $I d$. 
finding that "[i]t is the management of the life insurance policy that is 'integral to each of Bancorp's claims at issue,' not the computer machinery that may be used to accomplish it"; the determination of the values in the claims was "a matter of mere mathematical computation." 158

Notably, Bancorp Services did not explicitly reject, nor did it discuss, CLS Bank's "manifestly evident" rule. ${ }^{159}$ Rather, Bancorp Services distinguished the outcome in CLS Bank by saying that the computer limitations in CLS Bank played a "significant part in the performance of [that] invention or that the claims were limited to a very specific application ...." ${ }^{160}$ Even though Bancorp Services attempted to reconcile its holding with CLS Bank, these cases took fundamentally different approaches to analyzing the patent eligibility of software patents. ${ }^{161}$

Under the Bancorp Services approach, a court dissects a claim to determine whether there is an unpatentable abstract idea at its core. ${ }^{162}$ If there is, the court then determines whether any computer limitations are "integral" to the claimed invention. ${ }^{163}$ In contrast, the CLS Bank approach looks at a claim as a whole and seeks to determine whether it is "manifestly evident that [the] claim is directed to a patent ineligible abstract idea."

Given this disagreement, it is not surprising that the Federal Circuit decided to rehear CLS Bank en banc. The order granting the petition asked, "What test should the court adopt to determine whether a computerimplemented invention is a patent ineligible 'abstract idea'; and when, if ever, does the presence of a computer in a claim lend patent eligibility to an

158. Id. at 1279-80.

159. See id.; CLS Bank I, 685 F.3d 1341, 1352 (Fed. Cir. 2012), reh'g en banc granted, opinion vacated, 484 F. App'x 559 (Fed. Cir. 2012), aff'd en banc, 717 F.3d 1269 (Fed. Cir. 2013).

160. Bancorp, 687 F.3d at 1280 (citing CLS Bank I, 685 F.3d at 1355).

161. Dennis Crouch, Ongoing Debate: Is Software Patentable?, PATENTLY-O July 272012 , 3:53 PM), http://www.patentlyo.com/patent/2012/07/ongoing-debate-is-software-patentable.html ("Despite this attempted reconciliation, it is clear that the CLS majority has a different approach to subject matter eligibility questions [than Bancorp].”); see also Eric Guttag, Bancorp Services: Further Fracturing of the Patent Eligibility Landscape for Business Methods and Systems, IPWATCHDOG (July 27, 2012, 11:15 AM), http://www.ipwatchdog.com/2012/07/27/ bancorp-services-further-fracturing-of-the-patent-eligibility-landscape-for-business-methodsand-systems/id=26881/ (characterizing Bancorp as "yet more evidence of the further fracturing of the patent-eligibility landscape").

162. Bancorp, 687 F.3d at 1276.

163. Id. at 1278 .

164. CLS Bank I, 685 F.3d 1341, 1352 (Fed. Cir. 2012), reh'g en banc granted, opinion vacated, 484 F. App'x 559 (Fed. Cir. 2012), aff'd en banc, 717 F.3d 1269 (Fed. Cir. 2013) (emphasis added). 
otherwise patent-ineligible idea?"165 In the following Part, I argue that the point-of-novelty approach answers the question the Federal Circuit presented.

\section{A POINT-OF-NOVELTY RESOLUTION}

Because Mayo only identified categories of claim limitations that failed to render an unpatentable concept patent eligible, many worried that Mayo might radically limit patent-eligible subject matter. ${ }^{166}$ One commentator went so far as to say that the decision "creates a framework for patent eligibility in which almost any method claim can be invalidated."167 My earlier essay, Moderating Mayo, offered a more restrained interpretation of the Supreme Court decision. I argued that Mayo implicitly adopted a point-of-novelty approach, and that this approach did not need to radically limit patent eligibility in the way many feared. ${ }^{168}$

The point of novelty is the claim limitation or limitations that correspond to the heart or gist of the invention. ${ }^{169}$ Historically, patent law has refused to consider a patent's point of novelty in a wide-ranging number of doctrines. ${ }^{170}$ Both Mark Lemley and I have separately criticized that jurisprudence. As Lemley said, "It makes little sense for a law focused on invention to pay no attention to what is inventive about the patentee's technology." ${ }^{\prime 11}$ More

165. CLS Bank II, 484 F. App'x 559, 559 (Fed. Cir. 2012) (order granting hearing en banc). The order also asked whether the form of the claim matters (i.e., method, system, or storage medium claims). Id. at 559-60.

166. See, e.g., Gene Quinn, Killing Industry: The Supreme Court Blows Mayo v. Prometheus, IPWATCHDOG (Mar. 20, 2012, 1:44 PM), http://www.ipwatchdog.com/2012/03/20/ supreme-court-mayo-v-prometheus $/ \mathrm{id}=22920$ / ("The sky is falling! ... Those in the biotech, medical diagnostics and pharmaceutical industries have just been taken out behind the woodshed and summarily executed ....."); see also supra note 19.

167. Robert R. Sachs, Punishing Prometheus: The Supreme Court's Blunders in Mayo v. Prometheus, PATENTLY-O (Mar. 26, 2002, 8:10 AM), http://www.patentlyo.com/patent/ 2012/03/punishing-prometheus-the-supreme-courts-blunders-in-mayo-v-prometheus.html.

168. Chao, supra note 15, at 425.

169. See Aro Mfg. Co. v. Convertible Top Replacement Co. 365 U.S. 336, 344-45 (1961) ("[T]here is no legally recognizable or protected 'essential' element, 'gist' or 'heart' of the invention in a combination patent.").

170. Bernard Chao, Breaking Aro's Commandment: Recognizing that Inventions Have Heart, 20 Fordham InTEll. Prop. MEDia \& ENT. L.J. 1183, 1192 (explaining that the point of novelty has been rejected in assessing direct infringement, anticipation, obviousness, the written description requirement, and repair and reconstruction).

171. Lemley, Point of Novelty, supra note 130, at 1274-75; see also Kevin Emerson Collins, Getting into the "Spirit" of Innovative Things: Looking to Complementary and Substitute Properties to Shape Patent Protection for Improvement, 26 BERKELEY TECH. L.J. 1217, 1237 (2011) (arguing that the failure to consider the point of novelty is "highly problematic in the context of patent protection for improvements."). 
specifically, I argued that the point of novelty "should play an important role" in subject matter patent eligibility determinations. ${ }^{172}$ The Mayo Court appears to implicitly embrace this view. Mayo's approach assessed whether a patent's point of novelty was an unpatentable concept (i.e., law of nature, natural phenomenon, or abstract idea) and then determined whether any claim limitations somehow transformed that concept into a patent-eligible application. ${ }^{173}$

To be clear, Mayo's approach is very different from the point-of-novelty approach the Supreme Court applied years ago in Parker v. Flook. ${ }^{174}$ The claims in Flook involved a new formula for calculating an alarm limit for a catalytic chemical conversion of hydrocarbons. ${ }^{175}$ The claimed process contained three steps: "an initial step which merely measures the present value of the process variable (e.g., the temperature); an intermediate step which uses an algorithm to calculate an updated alarm-limit value; and a final step in which the actual alarm limit is adjusted to the updated value." ${ }^{\prime 176}$ The Supreme Court found that the invention was not patent-eligible "because once [the] algorithm is assumed to be within the prior art, the application, considered as a whole, contains no patentable invention."177 Thus, Flook suggested that a claim's point of novelty could not be based on an unpatentable concept. ${ }^{178}$

Diehr appears to have later rejected the Flook point-of-novelty analysis, ${ }^{179}$ and Mayo did not revive it. Although Mayo also focused on a patent's point of novelty, the decision did not assume that the point of novelty was in the prior art and require that other limitations be "new." Rather, Mayo focused on the natural law that corresponded to the claimed point of novelty and asked if the other limitations added enough to that concept to render the

172. Chao, supra note 170, at 1220. But see Lemley, supra note 130, at 1278-79 (expressing concern about relying on the point of novelty when making subject matter eligibility determinations).

173. Mayo Collaborative Servs. v. Prometheus Labs., Inc., 132 S. Ct. 1289, 1297-98 (2012).

174. Compare id., with Parker v. Flook, 437 U.S. 584 (1978).

175. Flook, 437 U.S. at 586.

176. Id. at 585 (footnotes omitted).

177. Id. at 594 .

178. See id.

179. Compare id., with Diamond v. Diehr, 450 U.S. 175, 188 (1981) ("In determining the eligibility of [a] claimed process for patent protection under $\int 101$, [the] claims must be considered as a whole. It is inappropriate to dissect the claims into old and new elements and then to ignore the presence of the old elements in the analysis."), and Mayo Collaborative Servs. v. Prometheus Labs., Inc., 132 S. Ct. 1289 (2012). 
claim patent eligible. ${ }^{180}$ That inquiry went far beyond whether the other limitations simply added something new and non-obvious. ${ }^{181}$ Thus, there is no reason to believe that an application based on a newly discovered formula or natural law is categorically unpatentable under Mayo.

Unfortunately, the Supreme Court only explained when certain limitations failed to add enough to an unpatentable concept. Mayo did not explain what kind of limitation could be added to an unpatentable concept to render it patent-eligible. My earlier proposal attempted to fill in that gap and offer a new point-of-novelty framework (i.e., one different from Flook). Relying on concepts already found in existing $\int 101$ jurisprudence, I offered a two-part test for determining when patents cover subject matter that should be patent eligible. ${ }^{182}$ Courts should first examine the limitation that embodies the point of novelty to determine whether it describes an unpatentable concept (i.e., a law of nature, a natural phenomenon, or an abstract idea) ${ }^{183}$ If it does, the court should then determine whether the other limitations bring the concept into the realm of patentable subject matter. ${ }^{184}$ This occurs when the other limitations are both concrete and strongly connected to the point of novelty. ${ }^{185}$

The point of novelty of many software patents is often an abstract idea. It could be a mathematical formula or a new way of doing business. Understanding that ideas themselves cannot be claimed, patent attorneys typically draft software patent claims to include a concrete physical device like a computer or the Internet. ${ }^{186}$ They hope that by adding these limitations, an otherwise unpatentable abstract idea may be rendered patentable. Under the point-of-novelty approach, this tactic would only work for certain kinds of patents.

180. Mayo, 132 S. Ct. at 1297-98.

181. See supra Section III.B.

182. Chao, supra note 15 , at $426,436$.

183. Id. at 436 .

184. Id.

185. Id.

186. See Robert A. King, Developing A Successful Intellectual Property Program, in DeVeloping a PATENT STRATEgy 117, 2011 WL 1120279 (Aspatore 2011) ("The machine or transformation test represents a 'safe harbor' for claim drafting. Many patent practitioners draft claims to meet this test, and, in many cases, starting with the minimum amount of machine-related references in the claims."); John R. Allison \& Starling D. Hunter, On the Feasibility of Improving Patent Quality One Technology at a Time: The Case of Business Methods, 21 BERKELEY TECH. L.J. 729, 736 (2006) ("[A]ttorneys had little difficulty drafting patent applications on software as though they claimed machines and devices of a more traditional physical nature."); David R. Heckadon, Six Months After Bilski: Practical Claim Drafting Tips for Software and Business Method Patents, GORDON \& REES LLP (Nov. 2010), http://www.gordonrees.com/publications/viewPublication.cfm?contentID=1705. 
The key is to test the strength of the nexus between the point of novelty and any additional concrete claim limitations. There may be a number of ways of characterizing such a test. I suggest that when the unpatentable concept and the additional limitations are bound together and necessary to achieve the goal of the claimed invention, the nexus is sufficiently strong to be patent eligible. One way to assess whether the concept is sufficiently bound together with the other limitations is to determine if the concept stands by itself. For example, consider Bilski's idea of hedging risk in a particular industry. ${ }^{187}$ Computer limitations could be added to the concept, but the concept would make sense standing by itself and therefore remain ineligible for patenting. Moreover, just because a computer or other physical device may be useful or practically necessary does not mean that the claim should be patent eligible. This means that a patent's goal cannot be characterized as merely applying a concept in a manner that is more efficient, faster, or more cost-effective by simply using a computer to conduct the process.

Although this Article is the first to articulate the "bound together" standard, the idea of testing the connection between the unpatentable concept and other limitations is already scattered throughout existing subject matter patent eligibility jurisprudence. The machine prong of the machine-ortransformation test examines how strong the nexus is between the unpatentable concept and other more concrete claim limitations (i.e., machines). More recently, Bancorp's requirement that a computer must be "integral to the claimed invention" tests the same connection. ${ }^{188}$ The Supreme Court has repeatedly stated that adding insignificant post-solution limitations does not make an abstract idea patentable. ${ }^{189}$ But this is simply another way of saying that the nexus between the unpatentable concept and its other limitations is not sufficiently strong.

If these threads existed by themselves, the law would not be so fractured. It would coalesce around a point-of-novelty approach. Unfortunately, the courts have also included many other unrelated factors that confuse subjectmatter eligibility determinations. Cases uniformly suggest that claims that sweep too broadly are less likely to be patent eligible. ${ }^{190}$ Consequently, they

187. See Bilski v. Kappos, 130 S. Ct. 3218, 3222 (2010).

188. See Bancorp Servs. v. Sun Life Assurance Co., 687 F.3d 1266, 1278 (Fed. Cir. 2012) (citing SiRF Tech., Inc. v. Int'l Trade Comm'n, 601 F.3d 1319, 1333 (Fed. Cir. 2010)).

189. Mayo Collaborative Servs. v. Prometheus Labs., Inc., 132 S. Ct. 1289, 1301 (2012); Bilski, 130 S. Ct. at 3231; Diamond v. Diehr, 450 U.S. 175, 191-92 (1981); Parker v. Flook, 437 U.S. 584, 590 (1978).

190. Mayo, 132 S. Ct. at 1301; Bilski, 130 S. Ct. at 3231 ("Allowing petitioners to patent risk hedging would pre-empt use of this approach in all fields, and would effectively grant a monopoly over an abstract idea."); Gottschalk v. Benson, 409 U.S. 63, 68 (1972) (stating that 
ask if a limitation has placed a meaningful limit on claim scope ${ }^{191}$ or preempted the entire idea. ${ }^{192}$ The Supreme Court has also pointed to Diehr and Flook as guideposts, suggesting that a claim is patent eligible if it is closer to Diehr and is not patent eligible if it is closer to Flook. ${ }^{193}$ As discussed earlier, these lines of inquiry suffer from both analytical and practical problems. ${ }^{194}$ But just as importantly, these inquiries obscure what should be the proper inquiry - assessing the strength of the connection between the unpatentable concept and the other claim limitations. Under the point-ofnovelty approach illustrated in this Article, these other lines of inquiry would not be used. ${ }^{195}$

The following examples illustrate how the point-of-novelty approach works. Consider the patent at issue in Diehr, which claimed a novel algorithm for curing rubber products. ${ }^{196}$ Both the formula and the physical components (the rubber molding press) were necessary to accomplish the invention's goal of making precision molded rubber products. ${ }^{197}$ Without the physical device, the formula could not achieve the goal of the invention. Moreover, it makes no sense to discuss the formula apart from the physical devices used to implement it. Thus, the connection between the idea and the device is sufficiently strong such that the subject matter should be patent eligible. The same analysis would also suggest that Flook was wrongly decided. ${ }^{198}$ The algorithm for updating the alarm limit of a catalytic chemical conversion of hydrocarbons was clearly bound together with industrial equipment and both limitations are necessary to perform the conversion. ${ }^{199}$ Accordingly, under

the claims before it were "so abstract and sweeping as to cover both known and unknown uses of the [mathematical formula]").

191. Dealertrack Inc. v. Huber, 674 F.3d 1315, 1333 (Fed. Cir. 2012); CLS Bank I, 685 F.3d 1341, 1351 (Fed. Cir. 2012), reh'g en banc granted, opinion vacated, 484 F. App'x 559 (Fed. Cir. 2012), aff'd en banc, 717 F.3d 1269 (Fed. Cir. 2013).

192. See, e.g., Bilski, 130 S. Ct. at 3258 (Breyer, J., concurring); Bancorp, 687 F.3d at 1280-81; Dealertrack, 674 F.3d at 1331.

193. See supra text accompanying notes 126-30.

194. See supra text accompanying notes 126-36.

195. Chao, supra note 15 , at 440.

196. Diamond v. Diehr, 450 U.S. 175, 177 (1981).

197. See id. at 189.

198. See supra text accompanying note 130 (discussing how the challenged patents in Flook and Diehr appear to be similar).

199. Perhaps the problem was that claim 1 did not explicitly connect the formula to physical device. But because the claim recited "the catalytic chemical conversion of hydrocarbons," Parker v. Flook, 437 U.S. 584, 596 (1978), the Court could have easily interpreted the claim to require such limitation or noted that adding such a limitation would render Flook's claims patent eligible. 
the point-of-novelty approach, Flook's invention would have been patent eligible.

However, in many other cases, the ideas underlying the software patents do not have strong connections to the devices. Consider the patents in CLS Bank, where the claims related to a trading system platform for exchanging obligations. ${ }^{200}$ The computer limitations were certainly very useful but were not fundamentally necessary for exchanging obligations. ${ }^{201}$ Moreover, the idea of exchanging obligations makes perfect sense standing alone; the nexus between the physical components and the underlying concept is weak. In CLS Bank, attaching the concept to a machine should not make the concept patentable.

The same analysis would apply to the patents in Ultramercial, Cybersource, and Dealertrack. The ideas underlying all these patents are not sufficiently bound together with their computer limitations to render them patent eligible. Ultramercial's idea of receiving free copyrighted content in exchange for viewing an advertisement does not clearly need the Internet. ${ }^{202}$ The idea makes sense without any physical devices. Cybersource's fraud detection patent examined Internet address information and compared it with other transactions utilizing the same credit card. ${ }^{203}$ Some type of computer may be necessary to obtain the Internet address information, but the idea of comparing addresses did not need to be performed on a computer, much less any physical device. Thus, this idea is not sufficiently connected to any concrete limitations. Finally, Dealertrack's patents merely automated a method of processing car loans. ${ }^{204}$ As a practical matter, computers were undoubtedly necessary to make the system operate efficiently. But that does not satisfy the revised point-of-novelty test. Since the underlying system could operate without computers, albeit inefficiently, the patents do not cover patent-eligible subject matter. Accordingly, none of these patents would survive the proposed point-of-novelty approach described here. ${ }^{205}$

200. CLS Bank I, 685 F.3d 1341, 1343 (Fed. Cir. 2012), reh'g en banc granted, opinion vacated, 484 F. App'x 559 (Fed. Cir. 2012), aff'd en banc, 717 F.3d 1269 (Fed. Cir. 2013).

201. See id. at 1358 n.1 (Prost, J., dissenting) (using a table to demonstrate how the steps of one of the claims at issue correspond to ordinary activities).

202. Ultramercial, LLC v. Hulu, LLC, 657 F.3d 1323, 1324 (Fed. Cir. 2011).

203. CyberSource Corp. v. Retail Decisions, Inc., 654 F.3d 1366, 1367-68 (Fed. Cir. 2011).

204. Dealertrack Inc. v. Huber, 674 F.3d 1315, 1317-18 (Fed. Cir. 2012).

205. I do not analyze the Bancorp Services patents because, for the most part, the Federal Circuit took the approach I advocate here. See supra text accompanying notes 154-57. 
As stated earlier, the digital image halftoning patents in Research Corporation Technologies $v$. Microsoft pose a more difficult case. ${ }^{206}$ The claims of Research Corporation Technologies ("RCT") revolved around a mathematical algorithm for determining how to display images for different devices like printers and displays. By itself the algorithm was clearly unpatentable. ${ }^{207}$ But all the claims added some limitations to this algorithm. At its barest, one method claim merely applied the algorithm to produce "dot profiles." ${ }^{208}$ Other claims also required a computer. ${ }^{209}$ Still other claims added physical components like "high contrast film," "a film printer," and "printer and display devices." 210

Under the point-of-novelty approach, the test is whether these limitations are both concrete and strongly connected to the mathematical algorithm that lies at the patents' point of novelty. The last set of claims presents the easiest case. Clearly, "high contrast film," "a film printer," and "printer and display devices" are concrete. Moreover, the nexus between these devices and the mathematical algorithm is strong. Using an algorithm to calculate the proper way to display particular dots is tightly linked with the display devices themselves. Making those calculations without some form of display device achieves nothing. Therefore, under the point-of-novelty approach, these claims would cover patent-eligible subject matter.

The more difficult question arises when these physical components are not recited by a given claim. This leaves only the dot profiles and the computer components to consider. Even though the computer limitations are concrete, they do not have a strong nexus with the underlying mathematical algorithm. There is no special connection between a computer and the algorithm for calculating how to display images. Presumably, the mathematical algorithm can be calculated without the use of a computer. A computer merely makes the calculations faster. So the computer limitations do not "add enough" to make the algorithm patent eligible. ${ }^{211}$

206. Research Corp. Techs. Inc., v. Microsoft Corp., 627 F.3d 859 (Fed. Cir. 2010); see also supra text accompanying notes 64-66.

207. See Diamond v. Diehr, 450 U.S. 175, 187 (1981); see also Gottschalk v. Benson, 409 U.S. 63, 67 (1972) (holding that a mathematical expression is simply a "scientific truth" and unpatentable (quoting Mackay Radio \& Tel. Co. v. Radio Corp., 306 U.S. 86, 94 (1939))). But the claims were not drawn to the algorithm standing alone. Consequently, the Federal Circuit stated that the claims were not "manifestly abstract" and found that the claims covered patent eligible subject matter. Research Corp., 627 F.3d at 869.

208. See Research Corp., 627 F.3d at 865 (reciting claim 1 of the ' 310 patent).

209. See, e.g., id. at 865-66 (reciting claims 1, 4, and 57 of the '772 patent).

210. Id. at 869.

211. See Mayo Collaborative Servs. v. Prometheus Labs., Inc., 132 S. Ct. 1289, 1297 (2012) (establishing the "add enough" requirement). 
But what about the dot profiles? Perhaps these limitations can render the algorithm patent eligible. However, the claimed dot profiles are not physical dots. The limitations actually refer to data that represents how dots are to be printed or displayed. This appears to be a close call. But allowing data that represents concrete objects to satisfy the point of novelty test reopens the door for business method patents. ${ }^{212}$ Thus, the "dot profile" limitations should not be considered sufficiently concrete to transform the unpatentable algorithm into patent-eligible subject matter.

This result may appear inconsistent with the goals of providing patent protection to industrial software. But the point is not to give all claims directed at an industrial software protection. The claims still must be drafted to include concrete limitations (e.g., printers or displays). That is why some of RCT's claims survived the point-of-novelty approach and others did not. This has the benefit of limiting claim scope_an outcome that both courts and commentators have sought to make an explicit requirement of $\$ 101$ analysis. ${ }^{213}$ Although the point-of-novelty approach does not have such an explicit requirement, the RCT example shows how the approach has a claim narrowing effect.

Some critics may argue that the point-of-novelty test proposed here will not make it easier to assess patentable subject matter eligibility. There will, of course, be some close cases, and the "bound together" and "necessary" language is not a magic bullet that will provide sudden clarity. When applying this test, the courts need to appreciate the basis for it. First, the test was designed with the understanding that the Supreme Court wants to do away with most business method software patents. Second, the test uses and expands upon the point-of-novelty approach found in Mayo. With this understanding, the Federal Circuit can achieve greater clarity as it works through several examples.

In sum, the point-of-novelty approach respects Bilski's hostility to business method patents while operating within the analytical framework required by Mayo. The result will be that most business method software patents will be declared ineligible because the connection between the concepts underlying those patents and the computers that they use is not strong. However, most industrial software patents will remain patent-eligible because the concepts underlying these inventions are bound together with specific physical devices.

212. See, e.g., Dealertrack, Inc. v. Huber 674 F.3d 1315, 1319-20 (Fed. Cir. 2012) (where the claims contained limitations directed toward credit card applications).

213. See notes 133-34 and accompanying text; Lemley et al., supra note 44, at 1317 (proposing that the test for patent eligibility under $\int 101$ be based solely on overclaiming). 
In February 2013, after this Article was accepted for publication, the Federal Circuit heard oral arguments in the en banc hearing of CLS Bank. ${ }^{214}$ Interestingly, the U.S. Patent and Trademark Office ("USPTO") took a similar position to the one advocated here. In response to questions from Judge Moore, Deputy Solicitor Nathan Kelly argued that a claim does not become patent-eligible simply because it contains computer limitations. ${ }^{215} \mathrm{He}$ argued that one must "look deeper into the claim to see if the system and steps are inseparable." 216 The term "inseparable" is another way of assessing the strength of the connection between the point of novelty and any additional concrete claim limitations. Although the USPTO's brief did not use the "inseparable" language, it did characterize the same concept in yet another way. It said that a claim must incorporate "meaningful limitations" (i.e., a limitation that is not a "mere field-of-use limitation, a tangential reference to technology, insignificant, extra-solution activity, an ancillary data-gathering step, or the like.”). ${ }^{217}$ The patent office's brief also suggested six factors for making this determination. ${ }^{218}$ Although some of these factors merely parrot back language from precedent, together they act much like the proposed "bound together and necessary" test. Dennis Crouch has

214. See Oral Argument, CLS Bank Int'l v. Alice Corp., No. 2011-1301 (Fed. Cir. Feb. 8, 2013) (en banc), available at http://oralarguments.cafc.uscourts.gov/default.aspx?fl=20111301_282013.mp3 (for an audio recording of the argument).

215. See id. at 28:00-28:41.

216. See id. at $28: 41$.

217. Brief for the United States as Amicus Curiae on Rehearing En Banc in Support of Neither Party at 7, CLS Bank III, 717 F.3d 1269 (Fed. Cir. 2013) (en banc).

218. The factors are:

[1] whether the computer is recited in a manner that is only nominally or tangentially related to the performance of the invention ...; [2] whether the computer is generically recited in a manner that would encompass any machine capable of performing the claimed steps, or whether specific, unconventional computer equipment, tools, or processing capabilities are required; [3] whether the invention involves an improvement in the ability of the computer to function as a computer, or whether the invention relates principally to an unrelated, non-technological field ...; [4] whether the claim recites a computerized device that manipulates particular data in particular, specific, and useful ways ... or whether the computer is recited solely for its generic functions of automating tasks or communicating over a distance; [5] whether ... the abstract idea is bound up in an invention that effects a transformation of matter, or whether ... the abstract idea is merely described in a particular environment; and [6] whether the computer-related elements of the claim represent conventional steps, described at a high level of generality, that would have to be employed by any person who wished to apply the abstract idea.

Id. at 13-14 (citations omitted). 
characterized this as an "odd ball" approach. ${ }^{219}$ But, as this Article has argued, this approach sensibly brings together the Supreme Court precedent.

\section{POSTSCRIPT: A DEEPENING SCHISM}

The Federal Circuit issued its en banc decision in CLS Bank on May 10, 2013. ${ }^{220}$ As discussed earlier, the patents concerned exchanging obligations using a third party to eliminate risk. ${ }^{221}$ The patents contained three types of claims directed (1) towards methods of exchanging obligations between parties, (2) data processing systems, and (3) computer readable media containing programs for exchanging obligations. The parties stipulated that all the claims required a computer. ${ }^{222}$ Although the two-paragraph per curiam opinion affirmed the district court's decision finding all the claims patentineligible, the judges were badly divided and the decision failed to give the guidance that so many followers of the court sought. ${ }^{223}$ The court was split five to five on the eligibility of the system claims. While seven judges did find that the method and computer-readable claims at issue were not patenteligible, those judges could not agree on the rationale for this conclusion. In fact, no approach was endorsed by a majority of the judges.

The decision contained seven separate opinions reflecting roughly three analytical approaches. These approaches roughly correspond to opinions written by Judge Lourie, Chief Judge Rader, and Judge Newman. For convenience, this Article breaks down the decision into the "strong view" and the "weak view" of $\int 101$ 's patent-eligibility requirement. The strong view corresponds to Judge Lourie's opinion (joined by Judges Dyk, Prost, Reyna, and Wallach). The weak view corresponds to Chief Judge Rader's first opinion (joined by Judge Moore and joined in part by Judges Linn and O’Malley), Judge Moore's opinion (joined by Chief Judge Rader, Judge Linn, and Judge O’Malley), Judges Linn and O'Malley's opinion, and Chief Judge Rader's second opinion. Although Judge Newman's opinion represents a third distinct analytical approach, the end result would be similar to the weak view. Accordingly, a brief description of her view is included in Section V.B, infra, describing the weak view.

219. Dennis Crouch, CLS Bank v. Alice Corp: Oral Arguments Lead to More Questions, PATENTLY-O (Feb. 9, 2013), http://www.patentlyo.com/patent/2013/02/cls-bank-v-alicecorp-oral-arguments-lead-to-more-questions.html.

220. CLS Bank III, 717 F.3d 1269 (Fed. Cir. 2013).

221. See supra text accompanying notes 139-41.

222. CLS Bank III, 717 F.3d at 1275 (Lourie, J., concurring).

223. In fact, Chief Judge Rader went so far as to say that "nothing" in the en banc opinion "beyond our judgment has the weight of precedent." Id. at 1293 n.1 (Rader, C.J., concurring in part and dissenting in part). 


\section{A. The Strong VieW}

Judge Lourie's concurring opinion argued that none of the claims satisfied \101 and contains the strongest view of $\int 101$ 's subject matter patent-eligibility requirement. The opinion was joined by Judges Dyk, Prost, Reyna, and Wallach and thus represents the view of five Federal Circuit judges. Before describing its approach, the opinion took note of some "common themes" found in the Supreme Court's decisions regarding $\int 101 .^{224}$ "First and foremost is an abiding concern that patents should not be allowed to preempt the fundamental tools of discovery." 225 In other words, "claims should not be coextensive with a natural law, natural phenomenon or abstract idea." 226 Second, Judge Lourie characterized the cases as cautioning "against overly formalistic approaches to subject-matter eligibility that invite manipulation by patent applicants." 227 Third, Judge Lourie also said that the cases "urge a flexible, claim-by-claim approach to subject-matter eligibility that avoids rigid line drawing.",228

Relying on these principles, Judge Lourie then outlined an approach to determine whether a computer-implemented claim is patent-eligible. Assuming that the claim falls within one of the four statutory categories set out in $\int 101$ (i.e., process, machine, manufacture, or composition of matter), the first question to ask is whether the claim poses any risk of preempting an abstract idea. ${ }^{229}$ If it does, a court must then identify the "fundamental concept" that is wrapped up in the claim. ${ }^{230}$ The analysis then proceeds to preemption analysis and looks to whether the claim covers the entire abstract idea itself. ${ }^{231}$

The opinion's preemption analysis relies on examining the "inventive concept." According to Judge Lourie, an inventive concept must be added to the underlying unpatentable fundamental concept to render the claim patenteligible. ${ }^{232}$ In contrast to a fundamental concept, an inventive concept must be "a product of human ingenuity." "233 Moreover, the inventive concept should not be confused with the novelty or obviousness requirements of

224. CLS Bank III, 717 F.3d at 1280-82 (Lourie, J., concurring).

225. Id. at 1280.

226. Id. at 1281.

227. Id.

228. Id.

229. Id.

230. Id.

231. Id. at 1282 .

232. Id. at $1282-84$.

233. Id. at 1283 (quoting Diamond v. Chakrabarty, 447 U.S. 303, 309 (1980)). 


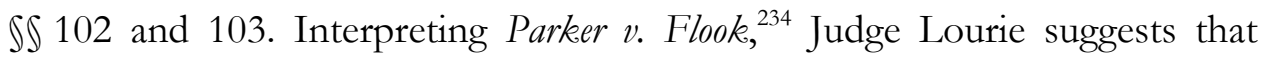
Flook only required that the claim contain an "inventive concept" to be patent-eligible.

For the most part, Judge Lourie defines an inventive concept in the negative. It "must represent more than a trivial appendix to the underlying abstract idea." 235 Thus, limitations that reflect the inventive concept are not "merely tangential, routine, well-understood, or conventional, or in practice fail to narrow the claim relative to the fundamental principle."236 "Bare fieldof-use limitations" do not qualify either. ${ }^{237}$ Having said what the inventive concept is not, the discussion of how to approach determining patenteligibility suddenly ends. Instead of explaining the positive characteristics of the inventive concept, the opinion simply acknowledges that it is not offering an "easy bright-line test," but rather one that depends on a "balance of factors." 238

Judge Lourie's opinion then proceeds to use this approach to analyze the claims. Starting with the method claims, the opinion identifies the underlying abstract idea - "reducing settlement risk by effecting trades through a thirdparty intermediary ... empowered to verify that both parties can fulfill their obligations before allowing the exchange-i.e., a form of escrow." ${ }^{239} \mathrm{Next}$,

234. Parker v. Flook, 427 U.S. 584 (1978).

235. CLS Bank III, 717 F.3d at 1283 (Lourie, J., concurring).

236. Id.

237. Id. at $1283-84$.

238. Id.

239. Id. at 1286. Judge Lourie's opinion analyzes claim 33 of the '479 patent as a representative method claim. It recites:

A method of exchanging obligations as between parties, each party holding a credit record and a debit record with an exchange institution, the credit records and debit records for exchange of predetermined obligations, the method comprising the steps of: (a) creating a shadow credit record and a shadow debit record for each stakeholder party to be held independently by a supervisory institution from the exchange institutions; (b) obtaining from each exchange institution a start-of-day balance for each shadow credit record and shadow debit record; (c) for every transaction resulting in an exchange obligation, the supervisory institution adjusting each respective party's shadow credit record or shadow debit record, allowing only these transactions that do not result in the value of the shadow debit record being less than the value of the shadow credit record at any time, each said adjustment taking place in chronological order; and (d) at the end-of-day, the supervisory institution instructing ones of the exchange institutions to exchange credits or debits to the credit record and debit record of the respective parties in accordance with the adjustments of the said permitted transactions, the 
the additional limitations- "creating shadow records, using a computer to adjust and maintain those shadow records, and reconciling shadow records and corresponding exchange institution accounts through end-of-day transactions" - were examined. ${ }^{240}$ Judge Lourie concludes that they do not add "anything of substance to the claim." 241

This conclusion is built upon three observations. First, Judge Lourie's opinion says that the claim lacks any express language to define the computer's participation. ${ }^{242}$ The computer simply acts as a calculator performing mental steps faster than a human could. Under the strong view, that is not sufficient to show the necessary inventive concept. ${ }^{243}$ Second, the opinion views the term "shadow record" as "extravagant language" that merely recites "a basic function required of any financial intermediary in an escrow arrangement." 244 Finally, Judge Lourie characterizes the step of providing end-of-day instructions to reconcile the parties' accounts as a "trivial limitation." ${ }^{245}$ Consequently, Judge Lourie concluded that the method claim was not drawn to patent-eligible subject matter.

After having found the method claims ineligible, Judge Lourie's opinion was quickly able to dispense with the computer-readable medium and system claims. The opinion characterizes those ostensibly concrete computer limitations as claim drafting tactics that add nothing of substance. Specifically, the opinion says that claim 39 of the '375 patent, the representative computer-readable medium claim, is not "truly drawn to a specific computer readable medium, rather than to the underlying method."246 Moreover, the system claims merely "recite a handful of computer components in generic, functional terms that would encompass any device capable of performing the same ubiquitous calculation, storage, and connectivity functions required by the method claims."247 Accordingly, the opinion concluded that all the asserted claims were invalid under $\int 101$ for failure to recite patent-eligible subject matter. ${ }^{248}$

credits and debits being irrevocable, time invariant obligations placed on the exchange institutions.

Id. at 1285 .

240. Id. at 1286 .

241. Id.

242. Id.

243. Id.

244. Id. at 1287

245. Id.

246. Id. at 1288 (quoting Cybersource Corp. v. Retail Decisions Inc., 654 F.3d 1366, 1374-75 (Fed. Cir. 2011)).

247. Id. at 1290.

248. Id. at 1292. 
Although I agree with Judge Lourie's ultimate conclusion, I have two critiques of his approach to $\$ 101$. First, Judge Lourie overstates the significance of the "inventive concept" in Supreme Court precedent. Judge Rader's first opinion picks up on this flaw and says that Judge Lourie "imbues" the phrase with "a life that is neither consistent with the Patent Act's description of Section 101 nor with the totality of Supreme Court precedent...."249 I agree. As Chief Judge Rader points out, the Flook decision that Judge Lourie relies upon only mentions the "inventive concept" once. ${ }^{250}$ The Mayo decision does not support Judge Lourie's reliance on the inventive concept either. ${ }^{251}$ Although Flook and Mayo use the phrase to suggest that a patent must claim something more than a natural law, the decisions do not gauge patent-eligibility by using the inventive concept. ${ }^{252}$ Judge Lourie just picks out that phrase to describe when additional limitations have added "enough" to render an otherwise unpatentable concept patent-eligible. Thus, his mistake is merely one of nomenclature, not substance. Nonetheless, relying on the term "inventive concept" provides room for critics to argue that Judge Lourie's opinion incorrectly interprets the controlling precedent.

The second difficulty with Judge Lourie's approach is more problematic. The opinion relies on already established principles to say what is not an inventive concept. Thus, even if this approach were eventually adopted, it would not provide any practical insights for determining when limitations actually contain an inventive concept. In contrast, the point-of-novelty approach proposed in this Article explains when a claim is patent-eligible.

249. Id. at 1303 n.5 (Rader, C.J., concurring in part and dissenting in part).

250. Id. Moreover, Judge Lourie's opinion misinterprets Flook. Flook suggested that a fundamental concept be treated as if were found in the prior art, and the novelty and nonobviousness requirement had to be satisfied by the other claim limitations. Parker v. Flook 437 U.S. 584, 594 (1978). This interpretation of Flook is shared by many commentators, including this Author. See supra notes 173-80 and accompanying text; Lemley et al., supra note 44 , at $1335-36$.

251. See CLS Bank III, 717 F.3d at 1282 (Lourie, J., concurring) (citing Mayo and Flook to support the notion of the "inventive concept").

252. Mayo Collaborative Servs. v. Prometheus Labs., Inc., 132 S. Ct. 1289, 1294 (2012). In Mayo, the Court states:

[Prior decisions] insist that a process that focuses upon the use of a natural law also contain other elements or a combination of elements, sometimes referred to as an "inventive concept," sufficient to ensure that the patent in practice amounts to significantly more than a patent upon the natural law itself.

Id. However, commentators consistently use this phrase. See, e.g., Kevin Emerson Collins, Prometheus Laboratories, Mental Steps, And Printed Matter, 50 Hous. L. REV. 391, 402 (2012) (discussing the use of the phrase, "inventive concept"). 
First, the "bound together" standard tests the nexus between the additional limitations and the underlying unpatentable concept to determine when limitations add "enough." Moreover, by prominently relying on Bilski, the lower courts can look to business method software patents and industrial software patents as new guideposts for determining patent-eligibility questions. To be fair, the point-of-novelty approach described in this Article is not a bright line test either. But it should provide more clarity than the approach proposed by Judge Lourie and his allies.

\section{B. THE WEAK VIEW}

Chief Judge Rader authored two separate opinions. His first opinion, concurring in part and dissenting in part, was joined by Judges Linn (except part VI), Moore, and O'Malley (except part VI), and reflects a comparatively weak view of $\int 101$ 's subject matter patent-eligibility requirement. The first five parts of the opinion outline a specific approach for determining patenteligibility and argue that the system claims were patent-eligible under $\int 101$. Part VI distinguishes the method and computer-readable claims from the system claims, and argues that the former claims are not patent-eligible. Judges Linn and O'Malley disagreed with this conclusion and did not join part VI. Instead they wrote their own opinion explaining why the court should have found that the method and computer-readable claims were also patent-eligible. ${ }^{253}$ Since the distinction between Chief Judge Rader and Judge Linn's opinions revolves around different claim interpretations, and not how to approach subject matter patent-eligibility, Judge Linn's view does not represent a distinct approach. Therefore, the weak view discussed here still represents the view of four Federal Circuit judges. ${ }^{254}$

Chief Judge Rader's opinion begins in earnest in Part II and emphasizes the breadth of subject matter that is patent-eligible under $\int 101{ }^{255}$ After providing a lengthy analysis of the legislative history of $\mathbb{S} 101$, the part concludes by saying: "In sum, any analysis of subject matter eligibility for patenting must begin by acknowledging that any new and useful process,

253. Thus, of those judges who advocated for a weak interpretation of $₫ 101$, only Judges Rader and Moore still believed that the method and computer-readable claims were not patent eligible.

254. Judge Linn has recently taken senior status. 2012, UNITED STATES COURT OF APPEALS FOR THE FEDERAL CIRCUIT, http://www.cafc.uscourts.gov/2012. Therefore, he will no longer participate in any future en banc proceedings.

255. See, e.g., CLS Bank III, 717 F.3d at 1294 (Rader, C.J., concurring in part and dissenting in part) ("Underscoring its breadth, Section 101 both uses expansive categories and modifies them with the word 'any." "). 
machine, composition of matter, or manufacture, or an improvement thereof, is eligible for patent protection." 256

The opinion then goes on to discuss the judicial exceptions to patenteligibility under $\int 101$. Much like the proponents of the stricter view, Chief Judge Rader notes that a claim cannot merely cover an "abstract idea, law of nature, or natural phenomenon." Of course Chief Judge Rader's opinion strikes an entirely different tone than Judge Lourie's opinion, calling the exceptions "limited" 257 and pointing out that "[a]ny claim can be stripped down, simplified, generalized, or paraphrased to remove all of its concrete limitations, until at its core, something that could be characterized as an abstract idea is revealed." ${ }^{258}$

Under Chief Judge Rader's approach, the primary inquiry "is whether a claim includes meaningful limitations restricting it to an application, rather than merely an abstract idea." ${ }^{259}$ The opinion discusses different ways for determining whether a limitation is sufficiently meaningful. First, "a claim is not meaningfully limited if it merely describes an abstract idea or simply adds 'apply it.' "260 Second, a claim "will not be limited meaningfully if it contains only insignificant or token pre- or post-solution activity-such as identifying a relevant audience, a category of use, field of use, or technological environment." 261 Finally, "a claim is not meaningfully limited if its purported limitations provide no real direction, cover all possible ways to achieve the provided result, or are overly-generalized." 262 These three concepts are found in Supreme Court precedent and are also discussed by Judge Lourie. ${ }^{263}$ Consequently, they fail to illustrate how the proponents of the weak view of $\int 101$ differ from the proponents of the strong view. It is only when the opinion analyzes the system claims does Chief Judge Rader reveal how he would approach patent-eligibility questions for software patents.

256. Id. at 1297 (emphasis added).

257. Id.

258. Id. at 1298 .

259. Id. at 1299.

260. Id. at 1300 (citing Mayo Collaborative Servs. v. Prometheus Labs., Inc., 132 S. Ct. 1289, 1294, 1297 (2012)).

261. Id. at 1300-01 (citing Mayo, 132 S. Ct. at 1297-98; Bilski v. Kappos, 130 S. Ct. 3218, 3230-31 (2010); Diamond v. Diehr, 450 U.S. 175, 191-92 \& n.14 (1981)); Parker v. Flook 437 U.S. 584, 595 n.18 (1978).

262. CLS Bank III, 717 F.3d at 1301 (Rader, J., concurring in part and dissenting in part) (citing Mayo, 132 S. Ct. at 1300).

263. See discussion supra Section V.A. 
Chief Judge Rader's opinion starts with the system claims, which have the most concrete computer based limitations. ${ }^{264}$ The main thrust of Chief Judge Rader's opinion is that each system claim "does not claim anything abstract in its machine embodiments." ${ }^{265}$ In support of that conclusion, the opinion points out that the representative claim includes "at least four separate structural components: a computer, a first party device, a data storage unit, and a communication controller coupled via machine components to the computer and the first party device." 266 Relying on the specification, the opinion goes on to argue that the structural and functional limitations found in the claims should not be considered post-solution activity but integral to the performance of the claimed system. ${ }^{267}$ For example, the specification describes how different computer components operate. ${ }^{268}$ It also contains flowcharts that describe specific algorithms that support the recited functions. ${ }^{269}$ Finally, the opinion also examines the claims from a more intuitive level. Because the claims contain concrete computer based

264. In contrast, Judge Lourie's opinion begins with the method claims, which appear to recite the least concrete limitations. See supra note 239 and accompanying text.

265. CLS Bank III, 717 F.3d at 1306 (Rader, C.J., concurring in part and dissenting in part).

266. Id. at 1307. Chief Judge Rader's first opinion analyzed claim 26 of the ' 375 patent as a representative system claim. The claim recites:

A data processing system to enable the exchange of an obligation between parties, the system comprising: a communications controller, a first party device, coupled to said communications controller, a data storage unit having stored therein (a) information about a first account for a first party, independent from a second account maintained by a first exchange institution, and (b) information about a third account for a second party, independent from a fourth account maintained by a second exchange institution; and a computer, coupled to said data storage unit and said communications controller, that is configured to (a) receive a transaction from said first party device via said communications controller; (b) electronically adjust said first account and said third account in order to effect an exchange obligation arising from said transaction between said first party and said second party after ensuring that said first party and/or said second party have adequate value in said first account and/or said third account, respectively; and (c) generate an instruction to said first exchange institution and/or said second exchange institution to adjust said second account and/or said fourth account in accordance with the adjustment of said first account and/or said third account, wherein said instruction being an irrevocable, time invariant obligation placed on said first exchange institution and/or said second exchange institution.

Id. at 1306.

267. Id. at $1306-07$.

268. Id.

269. Id. 
limitations, Chief Judge Rader suggests that labeling the system claim an abstract concept "wrenches all meaning from those words, and turns a narrow exception into one which may swallow the expansive rule (and with it much of the investment and innovation in software)." 270

At this point, Chief Judge Rader's opinion goes on to discuss the method without the concurrence of Judges Linn and O'Malley. In contrast to the system claims, Chief Judge Rader's opinion found that the method claims were not drawn to patent-eligible subject matter. ${ }^{271}$ The opinion examined each limitation of the representative claim $^{272}$ and found that they were all inherent to the fundamental concept of an escrow. The fact that the parties had stipulated that the method claims required a computer was insufficient to save them. ${ }^{273}$ Chief Judge Rader said that "implicit reference to computer 'implementation' is not, by itself, enough." 274 In sum, Chief Judge Rader concluded that the claim as a whole simply encompassed an abstract concept-namely, the entire concept of "using an escrow to avoid the risk of one party's inability to pay.",275

In essence, Chief Judge Rader and his allies view the vast majority of claims that contain computer limitations as being patent-eligible. The concept of ignoring computer-based limitations because they are not integral to the underlying idea only applies for patents that lie on one end of the spectrum. Under this view, a claim that does no more than simply add a computer to an otherwise unpatentable idea remains unpatentable. But claims that describe how an idea is implemented on particular components should be patent-eligible, even if that description is extremely basic. Of

270. Id. at 1309; see also id. at 1319 (Moore, J., dissenting in part) ("Looking at these hardware and software elements, it is impossible to conclude that this claim is merely an abstract idea.").

271. Oddly, Chief Judge Rader's opinion does not explicitly analyze the computerreadable medium claims. However, he concludes in the same sentence that the "method and media claims" are not patent-eligible. Id. at 1313 (Rader, C.J., concurring in part and dissenting in part). Presumably, Chief Judge Rader is applying the same analysis to both types of claims.

272. See supra note 239 for the text of this claim, claim 33 of the ' 479 patent.

273. This is where Judges Linn and O'Malley disagree. Their opinion interprets the method claims more narrowly and argues that they require "more than the use of computer is some unspecified way." CLS Bank III, 717 F.3d at 1329-30 (Linn \& O'Malley, JJ., dissenting). Accordingly, Judges Linn and O’Malley would treat the method claims just as Chief Judge Rader treats the system claims. See id. at 1330.

274. Id. at 1312 (Rader, J., concurring in part and dissenting in part).

275. Id. 
course almost any patent attorney should be able to draft claims that meet this requirement. ${ }^{276}$

Although the proponents of the weak view ostensibly apply Supreme Court precedent, it is hard to reconcile their analysis with Bilski and Mayo. First, just one year earlier, Mayo had rejected a similar invitation to find "that virtually any step beyond a statement of a law of nature itself should transform an unpatentable law of nature into a potentially patentable application sufficient to satisfy $\int 101$ 's demands." 277 Second, the "intuitive" understanding of what an abstract idea is that both Judges Rader and Moore apply is clearly inconsistent with Mayo. Indeed, a second separate opinion, Chief Judge Rader complains that "equating the personalized medicinal effect of a human-created pharmaceutical in patients of different metabolic rates and genetic makeup with the speed of light is only possible in a netherworld of undefined judicial insights." 278 Clearly, the Supreme Court has a broader view of what an abstract idea is than Chief Judge Rader and his allies. Finally, the proponents of the weak view do not acknowledge the hostility to business method patents found in Bilski. ${ }^{279}$

It is hardly surprising that the proponents of the weak view seem at odds with what the Supreme Court has said. The judges who signed on to the opinion appear to be quite dissatisfied with the Supreme Court's recent patent-eligibility jurisprudence. Judge Moore (joined by Chief Judge Rader and Judges Linn and O'Malley) writes that she is "concerned that the current interpretation of $\$ 101$, and in particular the abstract idea exception, is causing a free fall in the patent system." ${ }^{\text {,280 }}$ Moreover, Chief Judge Rader's second opinion cites to Bilski and Mayo (as well as several Federal Circuit decisions) as evidence of the failure of $\int 101$ jurisprudence. ${ }^{281}$ In short, while the proponents of the weak view give an obligatory salute to the governing Supreme Court precedent, they suggest a very different approach. If anything, the opinions written by Judges Rader, Moore, and Linn/O'Malley appear to be more of a plea to the Supreme Court to lower the bar for patent eligibility and return it to the standard of the pre-Bilski and Mayo era.

Again, this Article does not explore the possibility of fundamental change to patent-eligibility requirements under $\ 101$. Others may do so. Perhaps the

276. See supra note 186.

277. Mayo Collaborative Servs. v. Prometheus Labs., Inc., 132 S. Ct. 1289, 1303 (2012).

278. CLS Bank III, 717 F.3d at 1335 (Rader, C.J., additional reflections). The opinion does not explicitly mention Mayo, but is clearly referring to that decision.

279. See supra notes 85-91 and accompanying text.

280. CLS Bank III, 717 F.3d at 1313 (Moore, J., dissenting in part).

281. Id. at 1333-36 (Rader, C.J., additional reflections). 
Supreme Court should throw in the towel and rethink how it approaches basic questions of patent eligibility. ${ }^{282}$ One such option is simply lowering the eligibility requirement along the lines suggested by Chief Judge Rader's opinion. But that view is not based on recent precedent. What is more, there are no signs that the Supreme Court will make such a radical shift. ${ }^{283}$ In the meantime, the point-of-novelty approach suggested by this Article deals with the here and now. By working within the confines of recent Supreme Court decisions, it sets forth a practical framework for determining patent-eligibility questions raised by software patents.

Finally, Judge Newman's opinion merits some attention. Judge Newman's opinion represents her views alone. Although she would have found the all the claims were patent-eligible, her approach differs from the proponents of the weak view. Like Judge Rader, Judge Newman views the attempts to interpret patent-eligibility under $\int 101$ as a failure. ${ }^{284}$ But her solution is quite a bit simpler than the proponents of the weak view. Judge Newman argues that so long as a patent falls within the "useful arts" listed in $\int 101$, the courts should only apply the "laws of novelty, utility, prior art, obviousness, description, enablement, and specificity." ${ }^{285}$ Again, this is clearly not the current state of the law. Moreover, because the Supreme Court just rejected this very argument in Mayo, Judge Newman's approach is unlikely to provide the realistic solution that this Article seeks. ${ }^{286}$

\section{CONCLUSION}

After the fractured decision in CLS Bank, the law is still in a state of flux and no one can say with certainty just what kind of software patents, if any, satisfy $\int 101$ 's patent-eligibility requirement. This Article attempts to identify a realistic path out of the current morass by describing a test for determining when software patents cover patent-eligible subject matter. Relying on bits and pieces from existing precedent, the proposed point-of-novelty approach reins in harmful business method software patents without affecting their more deserving industrial cousins. Moreover, the theory does so without

282. See Lemley et al., supra note 44.

283. See supra text accompanying note 277.

284. CLS Bank III, 717 F.3d at 1321 (Newman, J., concurring in part and dissenting in part) (" $[\mathrm{A}] \mathrm{n}$ all-purpose bright-line rule for threshold portal of section 101 is unavailable as it is unnecessary.").

285. Id. at 1322 .

286. Mayo Collaborative Servs. v. Prometheus Labs., Inc., 132 S. Ct. 1289, 1303 (2012) (rejecting the government's argument that $\iint 102,103$, and 112 can perform the proper screening function for patents). 
categorically declaring all business method patents ineligible, a step that the Supreme Court refused to take in Bilski.

In addition to answering an important doctrinal question, this Article also operates on a more theoretical level. It builds on earlier point-of-novelty works $^{287}$ and applies that thinking to one of the most vexing questions facing patent law today - patent eligibility determinations for software patents. This demonstrates that the proposed patent eligibility test is also rooted in a firm theoretical foundation. Moreover, by providing another example of a pointof-novelty solution, this Article hopes to reinforce the case for relying on point-of-novelty thinking more generally in patent law.

287. See generally Chao, supra note 15; Lemley, supra note 130; Chao, supra note 170. 